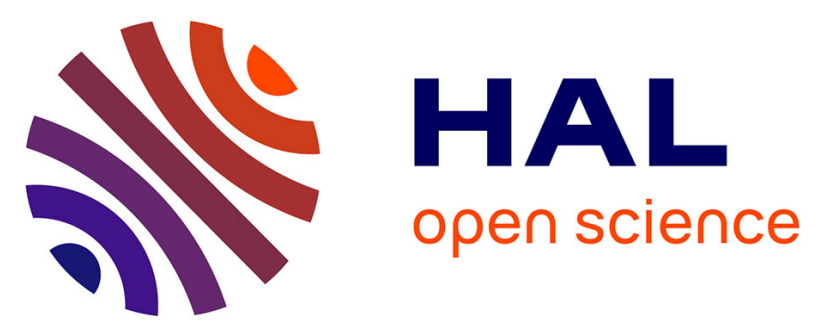

\title{
Aliphatic and aromatic biomarkers from Carboniferous coal deposits at Dunbar (East Lothian, Scotland): Palaeobotanical and palaeoenvironmental significance
} Maria-Fernanda Romero-Sarmiento, Armelle Riboulleau, Marco Vecoli, G. Versteegh, Fatima Laggoun-Défarge

\section{To cite this version:}

Maria-Fernanda Romero-Sarmiento, Armelle Riboulleau, Marco Vecoli, G. Versteegh, Fatima Laggoun-Défarge. Aliphatic and aromatic biomarkers from Carboniferous coal deposits at Dunbar (East Lothian, Scotland): Palaeobotanical and palaeoenvironmental significance. Palaeogeography, Palaeoclimatology, Palaeoecology, 2011, 309, pp.309-326. 10.1016/j.palaeo.2011.06.015 . insu00602822

\section{HAL Id: insu-00602822 \\ https://hal-insu.archives-ouvertes.fr/insu-00602822}

Submitted on 23 Jun 2011

HAL is a multi-disciplinary open access archive for the deposit and dissemination of scientific research documents, whether they are published or not. The documents may come from teaching and research institutions in France or abroad, or from public or private research centers.
L'archive ouverte pluridisciplinaire HAL, est destinée au dépôt et à la diffusion de documents scientifiques de niveau recherche, publiés ou non, émanant des établissements d'enseignement et de recherche français ou étrangers, des laboratoires publics ou privés. 
Aliphatic and aromatic biomarkers from Carboniferous coal deposits at Dunbar (East Lothian, Scotland): Palaeobotanical and palaeoenvironmental significance.

Maria-Fernanda Romero-Sarmiento a,1, Armelle Riboulleau a,", Marco Vecoli a, Gerard J. M. Versteegh ${ }^{\mathrm{b}}$, Fatima Laggoun-Défarge c

a Université Lille 1 \& CNRS FRE 3298, bâtiment SN5, 59655 Villeneuve d'Ascq cedex, France

b MARUM, Universität Bremen, Leobenerstraße, 28359 Bremen, Germany

c Université d'Orléans, CNRS/INSU - Institut des Sciences de la Terre d'Orléans UMR 6113. Campus Géosciences - 1A, rue de la Férollerie, 45071 Orleans cedex 2, France

* Corresponding author: Tel: +33 3204341 10; fax: +33 320434910

E-mail address: armelle.riboulleau@univ-lille1.fr

${ }^{1}$ Present address: IFP Energies nouvelles, Direction Géologie-

Géochimie-Géophysique, 1 et 4 avenue de Bois-Préau, 92852 Rueil-

Malmaison cedex

\section{ABSTRACT}


Carboniferous (Viséan) coals from Dunbar, East Lothian, Scotland, contain well-preserved miospore and megaspore assemblages suggesting a lycopod-dominated forest ecosystem with some ferns, sphenopsids and pteridosperms. The low rank of the coals and the well defined microflora permit assessment of the palaeoenvironmental significance of lipid biomarkers during Early Carboniferous times. RockEval, petrographic, and lipid analyses indicate a fully terrestrial depositional environment. Although we also present and discuss a wide diversity of other lipid biomarkers (alkanes, hopanoids, steroids), we focus on the terrestrial-derived biomarkers. Combustion-derived PAHs pyrene, fluoranthene, benzo[a]anthracene, chrysene and triphenylene indicate the occurrence of forest fires in the study areas during Early Carboniferous times. Alkyldibenzofurans derive from lichen-biomass. Retene, cadalene, simonellite, tetrahydroretene and kaurane are poorly specific and can derive from a variety of early Palaeozoic land plants. Abietane, phyllocladane, ent-beyerane and $4 \beta(\mathrm{H})$-eudesmane, as well as bisnorsimonellite, diaromatic totarane, diaromatic sempervirane and 2methylretene, however, as yet had only been reported from conifers, which do not appear in the fossil record until the Late Carboniferous. Within the lower Carboniferous forest ecosystem, arborescent lycopsids and pteridosperms are proposed as alternative sources for these compounds. 
Keywords: land plant biomarkers; terrestrial terpenoids; combustion derived-PAH; Lower Carboniferous coals; megaspores

\section{1. Introduction}

Biomarkers are molecular compounds which can be extracted from crude oils, coals and all kinds of sedimentary rocks (Tissot and Welte, 1984). Biomarkers have numerous biological origins, and their occurrence can be related to a specific source, giving information of the type of fauna/flora present in the environment, or to depositional conditions, such as salinity or temperature (Peters and Moldowan, 1993). For these reasons, biomarkers are regularly used in palaeoenvironmental studies (e.g. Olcott, 2007; Eglinton and Eglinton, 2008). Recent applications of biomarkers aim at tracing the evolution of life. In archean rocks, biomarkers give information on the timing and evolution of early forms of life (e.g. Brocks et al., 1999, 2003, 2005; Ventura et al., 2007 ; Eigenbrode et al., 2008 ; Waldbauer et al., 2009), while in more recent rocks and sediments, biomarkers help determining taxonomic relationships between taxa (e.g. Arouri et al., 2000; Talyzina et al., 2000). In the last decades, chemotaxonomic applications have been particularly developed for the study of flora associated with amber and coal deposits mostly of Mesozoic to recent age (e.g. Simoneit et al., 1986; Otto et al., 1997, 2002; Bechtel et al., 2005; Stefanova et al., 2005 among others). Chemotaxonomic studies of Palaeozoic land plant 
21 based on extractible biomarkers were developed in the 70's (Niklas, 1976a,b; Niklas and Chaloner, 1976; Niklas and Pratt, 1980) but have been relatively limited in more recent years (Schultze and Michaelis,

24 1990; Fleck et al., 2001; Auras et al., 2006), despite the interest of Palaeozoic plants regarding the evolution of terrestrial life.

The aim of this study is to identify and characterise aliphatic and aromatic biomarkers for Lower Carboniferous plants preserved in coals and to relate these biomarkers to specific plant taxa in order to apply chemotaxonomy to Palaeozoic land plants. Biomarker analyses were performed on four Lower Carboniferous (Viséan) coal samples from Dunbar, East Lothian, Scotland. Though megafossils are absent from these coals, their palynological content is rich and comprises abundant miospore and megaspore assemblages (Spinner, 1969; Spinner and Clayton, 1973). This gives us an opportunity to correlate the identified biomarkers with the occurrence of land plant palynomorphs and possibly to terrestrial plant groups or families.

\section{Geological setting and previous studies}

The Midland Valley of Scotland is a rift valley bounded by

40 Highland Boundary and Southern Uplands Faults on the North and the

41 South, respectively (Fig. 1; Murchison and Raymond, 1989; Underhill et

42 al., 2008). This sedimentary basin evolved in response to crustal

43 extension and especially contains Devonian to Carboniferous sediments 
44 and some igneous rocks (Murchison and Raymond, 1989; George, 1992;

45 Underhill et al., 2008). The Carboniferous rocks in the Midland Valley of

46 Scotland are only well exposed along coastlines (Murchison and

47 Raymond, 1989). Coal samples were collected from two outcrop sections

48 located at Dunbar, East Lothian, on the east coast of southern

49 Scotland, some $40 \mathrm{~km}$ East of Edinburgh (Fig. 1). These sections show a

50 group of alternating Lower Carboniferous (Viséan) limestones, shales,

51 sandstones and coals (Fig. 2.; Spinner, 1969; Spinner and Clayton, 52 1973).

SKT coal samples were collected around the bay near Skateraw

54 Harbour, approximately $6.4 \mathrm{~km}$ south-east of Dunbar, whereas WS

55 coals were taken from rock successions exposed in White Sand Bay

56 (Fig. 1). Both localities are clearly exposed on a geological map

57 permanently exhibited just above the shoreline. In stratigraphic order,

58 the lower seam is located immediately above the Middle Longcraig

59 Limestone: samples WS-2 and WS-3 (Fig. 2); the upper one (samples

60 SKT-E and SKT-D) occurs stratigraphically below the Chapel Point

61 Limestone (Fig. 2). WS samples are equivalent to the Longcraig coal

62 seam described by Spinner (1969). In contrast, SKT coals are more

63 comparable to the sample horizon SC2 detailed by Spinner and Clayton

64 (1973). In order to investigate the possible vertical stratigraphic

65 variations, two samples were obtained from each coal seam (Fig. 2).

66 Accordingly, WS coals are separated by approximately $30 \mathrm{~cm}$ while SKT

67 samples by $15 \mathrm{~cm}$. 
A fluvio-deltaic environment has been assigned to these

Carboniferous coals, which contain mainly land-plant derived organic matter (George, 1992). After deposition, these shallow-water deltaic deposits were mainly influenced by burial history and extensive volcanic, sill and dyke activities (Murchison and Raymond, 1989).

The sampled outcrop successions were previously studied palynologically (Spinner, 1969; Spinner and Clayton, 1973). Additional palynological analyses were performed for each of the collected samples for the present study. The WS coal interval is characterized by abundant and well-preserved megaspores such as (Spinner, 1969): Zonalesporites fusinatus Spinner 1969, Lagenicula subpilosa (Ibrahim) forma major Dijkstra ex Chaloner 1954 and Setosisporites (Ibrahim) Potonié and Kremp 1954 emend. Spinner 1969. Miospores are less abundant in this lower interval and are dominated by the following taxa: Lycospora pusilla (Ibrahim) Somers 1972 with Calamospora spp. and Densosporites spp. (Spinner and Clayton, 1973). All megaspore specimens recognized in the WS horizon (e.g. Lagenicula subpilosa,

85 Setosisporites and Zonalesporites fusinatus) range through the SKT coal 86 interval but Zonalesporites is less abundant (Spinner and Clayton, 87 1973). This upper interval also shows a notable diversity of miospores represented by Lycospora pusilla, Calamospora, Densosporites and

89 Cingulizonates $c f$. capistratus (Hoffmeister, Staplin and Mallow) Staplin 90 and Jansonius in Smith and Butterworth, 1967 (Spinner and Clayton, 91 1973). Megafossils are not known from these sediments. A megaspore- 
92 based flora reconstruction suggests that the vegetation consisted of

93 large arborescent lycopsids with long leaves together with some

94 diminutive forms (Spinner, 1969).

95

\section{Analytical methods}

\subsection{Experimental procedures}

The four coal samples (Fig. 2) were studied by Rock-Eval pyrolysis and biomarker analysis. Rock-Eval pyrolysis was performed on $100 \mathrm{mg}$

100 of ground rock with an Oil Show Analyser device at the University of

101 Paris 6 (France), using the conventional temperature program described

102 in Espitalié et al. (1986). The pyrolysis oven temperature was

103 programmed with $25^{\circ} / \mathrm{min}$ from $300^{\circ} \mathrm{C}$ (held $3 \mathrm{~min}$ ) to $650^{\circ} \mathrm{C}$ (held 3

$104 \mathrm{~min})$. However, due to the poor estimation of the total organic carbon

105 (TOC) content of coals by Rock-Eval analysis (Espitalié et al, 1986),

106 their TOC content was additionally determined on $100 \mathrm{mg}$ of powdered

107 decarbonated sample using a LECO carbon analyser at the same

108 university (Paris 6, France). The hydrogen index (HI) was calculated

109 using the Rock-Eval $\mathrm{S}_{2}$ and the LECO TOC values.

110 For biomarker analyses, rock fragments were extracted with

111 dichloromethane (DCM) during $24 \mathrm{~h}$ in the refrigerator, in order to

112 remove possible contamination on the sample surface. After this first

113 extraction, the rock fragments were crushed to enable extraction of the

114 lipids preserved inside the rock. Approximately $30 \mathrm{~g}$ of pulverised 
115 samples were extracted with a mixture of methanol $(\mathrm{MeOH})$ and

116 dichloromethane (DCM) $(1 / 2, v / v)$ for $24 \mathrm{~h}$ with extensive stirring. This

117 second extract was dried by means of roto-evaporation and partly re-

118 solubilized in cyclohexane. The cyclohexane-soluble fraction (maltenes)

119 was further separated by column chromatography.

120 The apolar fraction was recovered from the maltenes by elution

121 with cyclohexane on an activated silica column. Subsequent elution

122 with a mixture of cyclohexane - DCM $(2 / 1, \mathrm{v} / \mathrm{v})$ recovered the aromatic

123 fraction after which the polar fraction was recovered by elution with a

124 mixture DCM - MeOH $(2 / 1, \mathrm{v} / \mathrm{v})$.

125

126 3.2. Gas chromatography - mass spectrometry (GC-MS)

$127 \quad$ The aliphatic and aromatic fractions were analysed by gas

128 chromatography - mass spectrometry (GC-MS) using a ThermoFinnigan

129 Trace GC 2000 coupled to a ThermoFinnigan DSQ mass spectrometer.

130 The column used was a DB5ht (30 m length, $0.25 \mathrm{~mm}$ internal

131 diameter, $0.1 \mu \mathrm{m}$ film thickness). The oven temperature was

132 programmed as follows $100{ }^{\circ} \mathrm{C}$ for 1 minute, $100{ }^{\circ} \mathrm{C}-310^{\circ} \mathrm{C}$ at a rate of

$1334{ }^{\circ} \mathrm{C} / \mathrm{min}$ followed by an isothermal period of $16.5 \mathrm{~min}$ at $310^{\circ} \mathrm{C}$.

134 Helium was used as carrier gas. The mass spectrometer was operated in

135 the EI mode at electron energy of $70 \mathrm{eV}$. Samples were analysed in full

136 scan $(\mathrm{m} / \mathrm{z} 50$ - 700; scan rate $1000 \mathrm{amu} / \mathrm{s} ;$ scan speed $1.49 / \mathrm{s}$, scan 
137 time $0.67 \mathrm{~s})$. The organic compounds were identified by comparison of

138 their mass spectra and retention times with available published data.

139

\section{3.3. Organic petrography}

141 Maceral analyses and random vitrinite reflectance measurements

142 (expressed in \%) were carried out on embedded grain sections of two

143 coal samples (WS-3 and SKT-E) with a MPVIII Leica microscope using

144 an oil immersion objective (50 X) and following the procedures

145 described in ICCP (1975). Qualitative fluorescence analyses were also

146 performed using a blue light.

147

148 4. Results

149 4.1. Bulk OM characteristics

150 Bulk organic parameters obtained by Rock-Eval and LECO

151 analyses (Table 1) show that the TOC values for these coal samples

152 range between 60.8 and $71.9 \%$. HI and $\mathrm{T}_{\max }$ values vary between 144 to

$153218 \mathrm{mg} \mathrm{HC} / \mathrm{g}$ TOC and 423 to $428^{\circ} \mathrm{C}$, respectively (Fig. 3). The average

$154 \mathrm{~T}_{\max }$ is $426^{\circ} \mathrm{C}$. Based on the constructed HI vs. $\mathrm{T}_{\max }$ diagram (Fig. 3;

155 Espitalié et al., 1986), coal samples plot in the Type II - III kerogen

156 region.

157

158

4.2. Maceral composition and vitrinite reflectance 
160 2). The two coals are dominated by vitrinite (47-49\%), mostly

161 corresponding to telocollinite (Table2; Fig. 4A). Exinite is the second

162 most abundant maceral group (24-26\%). It mostly corresponds to 163 microspores and ornamental macrospores (17-20\%) with a yellow to

164 yellow-brownish fluorescence, and leaf cuticles with a bright yellow

165 fluorescence (Fig. 4B). Resinous secretions presenting a bright yellow

166 fluorescence also are observed in both samples (Fig. 4C). Although

167 inertinite is the less abundant maceral, it nevertheless represents a

168 substantial fraction of the organic matter (18-20\%). This maceral group

169 is dominated by semi-fusinite and fusinite. These macerals correspond

170 to plant material which is partially or totally, respectively, charred or

171 oxidized. Pyrofusinite, distinguished from fusinite by the presence of

172 devolatilisation vacuoles which indicate combustion at high

173 temperature (Fig. 4D), also is present in significant proportion (5\%;

174 Table 2).

175 Vitrinite random reflectance values are $0.44 \%$ and $0.45 \%$ for SKT-

176 E and WS-3, respectively. These values show that the samples are both

177 subbituminous A coals and represent the beginning of the

178 bituminization interval.

180 4.3. Aliphatic hydrocarbons

181 4.3.1. Total aliphatic hydrocarbons 

extracts (Fig. 5) are dominated by a series of $n$-alkanes ranging from $\mathrm{C}_{13}$

184 to $\mathrm{C}_{30}$. The distribution of $n$-alkanes is relatively similar in all four

185 samples and the most abundant are $n-\mathrm{C}_{27}$ and $n-\mathrm{C}_{29}$ (Fig. 6). Long chain $186 \mathrm{C}_{23}-\mathrm{C}_{33} n$-alkanes are characterized by an odd-over-even

187 predominance with a maximum at $n-\mathrm{C}_{27}$ (Fig. 6). The carbon preference 188 index (CPI) ranges between 1.65 and 1.93 (Table 1). Series of $\mathrm{C}_{14}$ to $\mathrm{C}_{21}$ 189 acyclic isoprenoids dominated by norpristane $\left(\mathrm{C}_{18}\right)$, pristane $\left(\operatorname{Pr} ; \mathrm{C}_{19}\right)$ 190 and phytane $\left(\mathrm{Ph} ; \mathrm{C}_{20}\right.$ ), were also detected (Fig. 6). Pr is the most 191 abundant compound in all the samples except SKT-D, where the $n-\mathrm{C}_{27}$ 192 alkane is more abundant (Fig. 5). The Pr/Ph ranges from 7.33 to 14.67 193 (Table 1). The $\mathrm{Pr} / n-\mathrm{C}_{17}$ is more than 1 , whereas the $\mathrm{Ph} / n-\mathrm{C}_{18}$ is inferior 194 to 1 (Table 1 ; Fig. 7). Branched alkanes without odd or even chain 195 length predominance were also recognized in low abundance (Fig. 6).

196 Steranes, hopanes, bicyclic alkanes and several diterpanoids were 197 clearly detected in the aliphatic fractions (Fig. 5).

\subsubsection{Hopanoids}

200 Series of a $\beta$-hopanes were detected in all the samples by 201 monitoring the $m / z 191$ ion (Fig. 8). These compounds are dominated by $17 \mathrm{a}(\mathrm{H}), 21 \beta(\mathrm{H})$-hopanes $\left(22 \mathrm{R}\right.$ and $22 \mathrm{~S}$ epimers) from $\mathrm{C}_{27}$ to $\mathrm{C}_{33}$, with 203 a maximum at $\mathrm{C}_{29}$ or $\mathrm{C}_{30}$ hopanes (Fig. 8). 
$206 \beta \beta$-hopane was present in all the samples (Fig. 8). Tricyclic terpanes

207 and gammacerane were not observed.

\subsubsection{Steroids}

Steranes and diasteranes were detected in all the samples using

211 the characteristic fragment at $m / z 217$ (Fig. 9). Steranes are more

212 abundant than diasteranes and the distribution of these compounds is

213 similar in all the samples (Fig. 9). Steranes are dominated by the $\mathrm{C}_{29}$

$2145 a(H), 14 a(H), 17 a(H)-20 R$ regular sterane $\left(\mathrm{C}_{29} \alpha \alpha \alpha\right.$-sterane; Fig. 9 and

215 10), followed by an important contribution of the $\alpha \beta \beta$ isomer (Fig. 9).

216 Diasteranes are dominated by $\mathrm{C}_{29} \beta \mathrm{a}$-diasteranes. However, series of

$217 \mathrm{C}_{27}$ to $\mathrm{C}_{29}$ a $\beta$-diasteranes and $\mathrm{C}_{27}$ to $\mathrm{C}_{29} \mathrm{a} \beta \beta$-steranes were also

218 recognized in all the samples (Fig. 9). Additionally, short chain steroids

219 were also detected in low amounts. SKT coals show a marked

220 contribution of short chain $\mathrm{C}_{19}-\mathrm{C}_{20}$ steroids in comparison with WS

221 samples (Fig. 9).

222

223

\subsubsection{Bicyclic alkanes}

Seventeen bicyclic alkanes ranging from $\mathrm{C}_{14}$ to $\mathrm{C}_{16}$ carbon atoms

225 have been identified in the aliphatic extracts of the Scottish coals, using 
226 the expanded $\mathrm{m} / \mathrm{z} 109+123+179+193$ fragmentograms (Fig. 11).

227 Peak assignments for the identified bicyclic alkanes are summarized in

228 Table 3. Based on comparisons with the previously reported mass

229 spectra and the retention times, $4 \beta(\mathrm{H})$-eudesmane; $8 \beta(\mathrm{H})$-drimane;

$2308 \beta(\mathrm{H})$ - and $8 \alpha(\mathrm{H})$-homodrimanes were clearly detected (Fig. 11; Noble,

231 1986; Noble et al., 1987). These compounds are not present as the

232 major constituents of the aliphatic fractions (Fig. 5); however, they have

233 been found in relative significant proportion (Fig. 11). Most of other

234 identified bicyclic alkanes have been previously observed in coal

235 extracts (Noble, 1986; Noble et al., 1987).

236 The distribution of bicyclic alkanes is relatively similar in all four

237 coals and the most abundant are $\mathrm{C}_{14}$ bicyclic alkanes (Fig. 11; e.g.

238 Peaks b and c). 8$\beta(\mathrm{H})$-homodrimane (Fig. 11; Peak p) is present in

239 significant proportion in most samples except SKT-D, while the relative

240 abundance of peak $\mathrm{h}$ allows differentiate WS coals from SKT samples.

241 The relative abundance of $4 \beta(\mathrm{H})$-eudesmane and $8 \beta(\mathrm{H})$-drimane is

242 similar in all samples (Fig. 11; Peaks i and k; respectively).

\subsubsection{Tricyclic and tetracyclic diterpenoids}

The partial $m / z 109+123+193+233$ fragmentograms from the

246 aliphatic fractions of Lower Carboniferous coals reveal the presence of

247 eighteen tricyclic and tetracyclic diterpenoid hydrocarbons (Fig. 12).

248 Peak assignments for identified aliphatic diterpenoids are shown in 
249 Table 4. The tetracyclic diterpenoids $\left(\mathrm{C}_{20} \mathrm{H}_{34}\right)$ ent-beyerane (Peak XII), $25016 \beta(\mathrm{H})$-phyllocladane (Peak XIII), ent-16 $\alpha(\mathrm{H})$-kaurane (Peak XV), 16 $\alpha(\mathrm{H})$ 251 phyllocladane (Peak XVI) and ent-16ß(H)-kaurane (Peak XVII) were 252 mainly recognized, by comparison with the published mass spectra of 253 authentic compounds (Noble, 1986; Otto et al., 1997; also in Noble et 254 al., 1985; Philp, 1985; Schulze and Michaelis, 1990).

The peak labelled II has a mass spectrum characterized by a 256 strong fragment at $\mathrm{m} / \mathrm{z} 233$ (Fig. 12A). Based on its fragmentation pattern, compound II was tentatively identified as a $\mathrm{C}_{18}$ tricyclic hydrocarbon (Fig. 12). This latter compound is particularly abundant in SKT samples, as are $\mathrm{C}_{19}$ and $\mathrm{C}_{20}$ steranes, it could therefore be related to short chain steroids. To our knowledge, the molecular structures for most of the $\mathrm{C}_{18}-\mathrm{C}_{19}$ diterpenoids identified in this study, have not been previously established (see mass spectra in the appendix).

264 dominated by kaurane and phyllocladane. Kaurane isomers, however, 265 are slightly more abundant in SKT samples while phyllocladanes are more predominant in WS coals (Fig. 12). ent-Beyarane shows a

267 relatively similar contribution in all samples, and generally is present in 268 low amounts in comparison to the other $\mathrm{C}_{20}$ diterpenoids. The only tricyclic diterpenoid identified is abietane (Peak XIV; Fig. 270 12). It is present in relatively low abundance in all four samples. Its 271 contribution is however more significant in WS coals (Fig. 12). 



342 4.4.3. The land plant- and combustion-derived polycyclic aromatic

343 hydrocarbons

Among the polycyclic aromatic hydrocarbons (PAHs), two

345

particular groups have been recognized in these Scottish coals (Fig. 13;

346 Table 5). The first one includes the land-plant-derived PAHs retene (87),

347 cadalene (33), simonellite (74), bisnorsimonellite (57), tetrahydroretene

348 (70), diaromatic totarane (76), diaromatic sempervirane (90) and 2-

349 methylretene (94) whereas the second group comprises the combustion-

350 derived PAHs pyrene (75), fluoranthene (71), benzo[a]anthracene (96),

351 chrysene and triphenylene (97) (Fig. 13; Philp, 1985; Ellis et al., 1996,

352 Otto et al., 1997; Jiang et al., 1998 and references therein; van Aarssen

353 et al., 2000; Otto and Simoneit, 2001; Bastow et al., 2001, Tuo and

354 Philp, 2005).

355

Simonellite (74), diaromatic totarane (76) and diaromatic

356

sempervirane (90) (see also the expanded $\mathrm{m} / \mathrm{z} 237$ chromatograms; Fig.

357

20) were clearly identified by their mass spectra but the elution pattern

358

slightly differs from one presented in Tuo and Philp (2005). Following

359 the same principles as by Tuo and Philp (2005), another family of

360 diaromatic tricyclic hydrocarbons was detected in the aromatic fractions

361 (Fig. 20). These new, supposedly also diaromatic hydrocarbons (Tre ${ }^{1}$

362 and $\mathrm{Tr}^{2}$ ) have very similar mass spectra to tetrahydroretene, exhibiting

363 a base peak at $m / z 223$ and a molecular ion at $m / z 238$ (Fig. 20). Based 
364 on their mass spectra and elution times, comparison with the

365 distribution of the established diaromatic tricyclic hydrocarbons

366 simonellite, diaromatic totarane and diaromatic sempervirane (Otto et

367 al., 1997; Otto and Simoneit, 2001; Tuo and Philp, 2005), and the

368 identification of diaromatic totarane and sempervirane in our coals,

369 these compounds were tentatively identified as tetrahydroretene

370 isomers, based on the totarane and sempervirane skeletons,

371 respectively. Compound Tre $^{1}$ could be the 1-methyl-1,2,3,4-tetrahydro-

372 8-isopropylphenanthrene (totarane-derived) and $\mathrm{Tre}^{2}$ the 1-methyl-

373 1,2,3,4-tetrahydro-6-isopropylphenanthrene (sempervirane-derived; Fig.

374 20). Their molecular structures are also proposed in Figure 20.

375

376 5. Discussion

377

\subsection{Thermal maturity}

According to LECO results, the TOC values for these Scottish

samples are typical for coals (60.8 and $71.9 \%$; Table 1$)$. Based on such

380

values of TOC, the average $\mathrm{T}_{\max }\left(426^{\circ} \mathrm{C}\right)$ from Rock-Eval analyses, as

381

well as the vitrinite reflectance $(0.45 \%)$, the rank of the studied coals is

382 of subbituminous A, i.e. an immature stage of thermal evolution (Fig. 3).

383 This interpretation is supported by molecular thermal maturity

384 indicators from the aliphatic and aromatic fractions. First, the CPI is

385 high (>1) due to odd predominance (Table 1; Bray and Evans, 1961).

386 Second, the thermally unstable $\mathrm{C}_{29} \beta \beta$ hopane is observed in all samples 
387 (Fig. 8; Seifert and Moldowan, 1980). Third, the high thermal maturity

388 markers in sediments 18a-22,29,30-trisnorneohopane (Ts) and a $\beta \beta$ -

389 steranes (Fig. 9) are absent or very low in abundance (Seifert and

390 Moldowan, 1978, 1986). This is further attested by the aromatic

391 hydrocarbon distribution of MN, EN, DMN, TMN, TeMN and MP isomers again indicating that the coals are immature (Table 6; Radke et al., 1982, 1986; Alexander et al., 1985; van Aarssen et al., 1999). For

394 instance, the TeMN compounds show the predominance of $1,2,5,6-$ and 395 1,2,3,5-TeMN over the 1,3,6,7-TeMN (Fig. 16; van Aarssen et al., 1999). The distribution of methyl- and ethyl-naphthalene homologues with 2MN and 2-EN dominating is typical for immature samples (Fig. 14; Table 6; Radke et al, 1982). The alkylphenanthrenes 9-MP and 1-MP are highly abundant, with 9-MP being predominant (Fig. 17) is another 400 feature of immature samples (Radke et al., 1982). It is interesting to 401 note, however, that depending on the maturity index either WS or SKT 402 samples may be considered to be the more mature. WS samples are more mature with DNR, TNR1 and TNR2 while SKT samples are more

404 mature with TMNr, TeMNr, MPI 1 and MPI 2 (Table 6). This feature 405 probably reflects the control exerted by the source of the organic matter and depositional environment on these compounds at low maturity

407 degree.

408 
Like most coals, the investigated ones are typically terrestrial. This

411 is evidenced by petrographic examination (Table 2, Fig. 4), palynology

412 (Spinner, 1969; Spinner and Clayton, 1973), and biomarker

413 distributions. In addition to the typical odd numbered long-chain $n$ -

414 alkanes (Eglinton and Hamilton, 1967), several aliphatic and aromatic compounds generally used as terrestrial biomarkers have been detected 416 in our Carboniferous coals (Table 7).

417 The Carboniferous sedimentary rocks in the Midland Valley of 418 Scotland consist of cyclical sequences of coals, oil shales, limestones, 419 shales, mudstones, siltstones and sandstones (Murchison and 420 Raymond, 1989; George, 1992). Coals are usually deposited in swampy 421 terrestrial environments such as deltas and regions with poor drainage.

422 Accordingly, a variety of depositional environments, all relatively 423 shallow-water and predominantly deltaic, has been assigned to these 424 Carboniferous rocks (Murchison and Raymond, 1989). In the case of a 425 deltaic environment (such as in our case) marine intrusions may occur 426 which may be evidenced by means of palynomorphs and lipid 427 biomarkers. Since organic particles of marine origin, i.e. alginite and 428 marine palynomorphs, and marine biomarkers (e.g. cheilantanes) are 429 absent, the (low proportion of) short chain $n$-alkanes in our coals (Fig. 430 6) must be considered to be of bacterial rather than marine origin. 431 Other arguments for a purely terrestrial depositional environment 432 are the high $\mathrm{Pr} / \mathrm{Ph}$ (Table 1 ) and $\mathrm{Pr} / n-\mathrm{C}_{17}$ vs. $\mathrm{Ph} / n-\mathrm{C}_{18}$ ratios (Fig. 7; 433 Hunt, 1995). These ratios characterize the Scottish coals as Type III OM 
434 which is usually derived from terrestrial plants (Peters and Moldowan, 435 1993) deposited under oxidizing conditions, and in particular, the WS 436 coal level (Fig. 7).

437 A bacterial contribution to the $\mathrm{OM}$ is further evidenced by the 438 occurrence of branched alkanes (Fig. 6; e.g. Shiea et al., 1990), 439 hopanoids (Figs. 5 and 8; Ourisson et al., 1979) and bicyclic alkanes of 440 the drimane and homodrimane series (Fig. 11; Noble, 1986; Noble et al., 441 1987). Aromatic hydrocarbons often associated to a microbial source 442 include 1,2,3,5,6-pentamethylnaphthalene (1,2,3,5,6-PMN; Fig. 13; 443 Table 5; Bastow et al., 1998) and 1,3,6,7-tetramethylnaphthalene 444 (1,3,6,7-TeMN; Fig.16; e.g. Jiang et al., 1998). Steroids have also been used to differentiate depositional settings 446 (Peters et al., 2005). Huang and Meinschein (1979) proposed a useful 447 ternary diagram to identify the source of the OM which can be 448 constructed by the distribution of $\mathrm{C}_{27}, \mathrm{C}_{28}$ and $\mathrm{C}_{29}$ sterols (Fig. 10). 449 Based on their results, the dominant source of $\mathrm{C}_{27}$ sterols is zooplankton, $\mathrm{C}_{28}$ sterols are generally components of phytoplankton and $451 \mathrm{C}_{29}$ sterols are mainly derived from terrestrial plants. There are many 452 exceptions on these rules; for instance, $\mathrm{C}_{29}$ sterols are also found in marine diatoms and dinoflagellates (e.g. Rampen et al., 2010).

454 Nevertheless, the method seemed reliable for other Palaeozoic (Middle 455 Devonian) coals which have a high predominance of $\mathrm{C}_{29}$ steranes (e.g. 456 Fowler et al., 1991; Kashirtsev et al., 2010). Considering this, the 457 dominance of $\mathrm{C}_{29}$ relative to $\mathrm{C}_{27}$ steranes in these coals further 
458 evidences their terrestrial origin (Table 1; Fig. 9). Consistent with the

459 shallow-water environment proposed for Scottish coals (Murchison and

460 Raymond, 1989), the steroids plot in a transitional estuarine-bay

461 environment (Fig. 10). It is interesting to note that short chain $\mathrm{C}_{19}-\mathrm{C}_{20}$

462 steroids are abundant in SKT coals (Fig. 9). Although these compounds

463 are not commonly described from coals, they have been reported in a

464 Devonian liptobiolith (Kashirtsev et al., 2010). The relative abundance of

465 these $\mathrm{C}_{19}-\mathrm{C}_{20}$ steroids may be characteristic for some primitive coals, 466 suggesting that they could be more specific biomarkers of early plants.

467 The occurrence of the combustion-derived PAHs pyrene,

468 fluoranthene, benzo[a]anthracene, chrysene and triphenylene (Fig. 13)

469 can be related to the significant presence of the fusinite group, most

470 particularly pyrofusinite, in the organic matter. Charred or fusinized

471 plant debris have been frequently reported in coals from the Midland

472 Valley of Scotland (Murchison and Raymond, 1989; Scott and Jones,

473 1994; Falcon-Lang, 2000) and combustion-derived PAHs have been

474 observed in coal extracts (Murchison and Raymond, 1989). These

475 compounds and macerals testify that fire events took place

476 contemporarily with coal deposition. Fire events in coals are often

477 related to lightning, but in the case of the Midland Valley of Scotland,

478 volcanic activity also appears as a major cause of wildfires (Murchison

479 and Raymond, 1989; Scott and Jones, 1994; Falcon-Lang, 2000).

480

$481 \quad$ 5.3. Linking biomarkers, palynology and palaeobotany 
483 Spinner (1969) and Spinner and Clayton (1973), a relatively detailed

484 reconstruction of the flora giving rise to the SKT and WS coals can be

485 provided, though more details are available for SKT coals than for WS

486 coals. In WS coals, megaspores are dominated by Zonalesporites and/or

487 Setosisporites, followed by Lagenicula (Spinner, 1969). Cystosporites are

488 also present in minor proportion. In SKT coal, dominant megaspores are

489 Lagenicula and Setosisporites followed by ?Bacutriletes and

490 Zonalesporites (Spinner and Clayton, 1973). Miospores assemblages are

491 generally dominated by Lycospora, Calamospora and Densosporites

492 (Spinner and Clayton, 1973). Cingulizonates miospores should also be

493 abundant in SKT coal. The megaspore Zonalesporites as well as the

494 miospores Densosporites and Cingulizonates were mostly produced by

495 Bodeodendron/Sporangiostrobus (recently identified as equivalent to

496 Omphalophloios) which was a sub-arborescent lycopsid belonging to the

497 Isoetales group (Wagner, 1989; Taylor et al., 2009; Opluštil et al., 2010).

498 Bacutriletes miospores were produced by herbaceous and sub-

499 arborescent lycopsids among which Bodeodendron/Sporangiostrobus

500 (Eble, 1996). Setosisporites megaspores mainly derived from

501 Bothrodendron (e.g. Phillips, 1979). Lagenicula megaspores and some

502 Lycospora miospores were produced by Paralycopodites (also known as

503 Anabathra; DiMichele and Phillips, 1994). Finally, Cystosporites

504 megaspores and some Lycospora miospores were produced by

505 Lepidodendron (DiMichele and Phillips, 1994). Bothrodendron, 
506 Paralycopodites and Lepidodendron were arborescent lycopsids and

507 belonged to the Lepidodendrales group (Taylor et al., 2009). It must be

508 noted that these different plants are mostly documented from the Late

509 Carboniferous and afterwards, though the corresponding spores

510 appeared earlier, sometimes in the Devonian (Glasspool et al., 2000;

511 Opluštil et al., 2010). The plants from which these spores derived in

512 Viséan coals are not firmly identified, but it is highly probable that they

513 correspond to several groups or families of lycopsids (Glasspool et al.,

514 2000), in particular to Isoetales and Lepidodendrales which already

515 existed during the Viséan (Taylor et al., 2009). Accordingly, though the

516 same lycopsids were present in both coal levels, WS coals vegetation is

517 marked by a higher contribution of Isoetales (Bodeodendron-like) while

518 Lepidodendrales, and in particular Paralycopodites-like plants, were

519 more abundant in the vegetation of SKT coals. In addition to these

520 dominant plants, the miospore assemblages (Spinner and Clayton,

521 1973) document the presence of a notable contribution of Calamites

522 sphenopsids and of small ferns, in particular Botryopteridaceae and

523 Zygopteridaceae. Marattialean tree ferns and the arborescent lycopsid

524 Sigillariaceae are also indicated, as well as Lyginopteridacean

525 pteridosperms documented by the presence of the spore Schulzospora

526 (Spinner and Clayton, 1973). Lycopsids were abundant spore producers

527 (DiMichele and Phillips, 1994) and the abundance of spores observed in

528 the organic matter (Table 2; Fig. 4) supports a significant contribution

529 of lycopsids to our Scottish coals. By its diversity and dominance of 
530 lycopsids, this floral assemblage appears relatively comparable to the

531 anatomically preserved floras of Glenarbuck and Pettycur in Scotland

532 (Scott et al., 1984), which are of Viséan age but slightly older than our

533 studied coals. It is notable that although there are some Viséan records

534 of Cordaites (e.g. Wang, 1998), Cordaites remains were not reported

535 from Glenarbuck and Pettycur (Scott et al., 1984) nor Cordaite spores

536 (e.g. Florinites) in the palynofacies from our Scottish coals (Spinner,

537 1969; Spinner and Clayton, 1973).

538 The relatively similar lycopsid-dominated floras observed in SKT

539 and WS coals (Spinner, 1969; Spinner and Clayton, 1973) are

540 consistent with the relatively similar biomarker content observed in

541 both coals. Some aromatic biomarkers detected in this study can be

542 related to specific plant taxa (Table 7). For instance, the presence of

543 alkyldibenzofurans (MDBFs) indicates lichen input (Fig. 13; Radke et

544 al., 2000). Although lichen fossils or specific lichen spores have not

545 been reported in Scottish coals (Spinner, 1969; Spinner and Clayton,

546 1973), it can be safely assumed that Euramerican Coal Measure forests

547 were a good potential habitat for lichens. Among the less specific

548 biomarkers, the detected combustion-derived PAHs cannot be

549 associated to specific kind of plants (Oros and Simoneit 2000a,b; Oros

550 et al. 2006; Inuma et al., 2007). It is also the case for 1,6-

551 dimethylnaphthalene (1,6-DMN; Fig. 14), 1,2,5-trimethylnaphthalene

552 (1,2,5-TMN; Fig. 15), pimanthrene (1,7-DMP; Fig. 16) and cadalene,

553 which can be produced by aromatization of several different terpenoid 
structures and/or which precursors are widespread among terrestrial plants (Table 7 ). Ionene is a degradation product of $\beta$-carotene (Day and

556 Erdman, 1963). It is often observed in coal extracts (e.g. Wang and

557 Simoneit, 1990), but also can be produced from thermal degradation of 558 marine and lacustrine sediments (Day and Erdman, 1963; Achari et al., 1973). $4 \beta(\mathrm{H})$-eudesmane is another non-specific land plant biomarker.

560 This compound has been rarely observed in Palaeozoic coals (del Río et 561 al., 1994; Dzou et al., 1995) and is considered to derive from evolved 562 land plants such as angiosperms and gymnosperms (e.g. conifers;

563 Noble, 1986). However, bicyclic alkanes with an eudesmane skeleton 564 have been also identified in recent bryophytes (Asakawa, 2004). Its 565 oldest reported occurrence in sediments, to our knowledge, is Middle 566 Pennsylvanian (Dzou et al., 1995). The diterpenoids ent-beyerane, abietane, ent-kaurane and 568 phyllocladane have been previously described in Carboniferous (e.g. 569 Schulze and Michaelis, 1990; Fleck et al., 2001; among others) and 570 Permian coals (e.g. Noble, 1986; Noble et al., 1985). Abietane precursors 571 occur in all conifer families (Otto and Wilde, 2001; Cox et al., 2007) and 572 this compound has been recently described in the pyrolysate of Late 573 Carboniferous amber (Bray and Anderson, 2009). Kaurane skeletons 574 have been observed in different kinds of plants, and in particular 575 bryophytes (e.g. Noble, 1986; Chopra and Kumra, 1988; Asakawa, 576 2004). The occurrence of this component in very early terrestrial OM 577 (e.g. Sheng et al., 1992; Disnar and Harouna, 1994; Kashirtsev et al, 
578 2010; Romero Sarmiento et al., 2010) can be therefore related to

579 bryophytes, which represent the earliest land plants. Phyllocladane and

580 ent-beyerane have been mostly associated to all conifer families except

581 Pinaceae (e.g. Noble, 1986; Schulze and Michaelis, 1990; among

582 others). However, the oldest recorded occurrences of phyllocladane and

583 ent-beyerane are Serpukhovian (Fabianska et al., 2003; Izart et al.,

584 2006) and Middle Devonian (Sheng et al. 1992; Kashirtsev et al., 2010),

585 respectively. The occurrence of these compounds in Carboniferous

586 sediments that predated the evolution of conifers has been related to

587 the Voltziales (e.g. Schulze and Michaelis, 1990) and/or the close

588 relatives Cordaites (e.g. Disnar and Harouna, 1994 and references

589 therein), while in Devonian coals, these compounds were related to

590 pteridophytes (Sheng et al. 1992).

591 The relative abundance of tricyclic and tetracyclic diterpenoids in

592 coals is affected by the palaeobotanical and palaeoenvironmental

593 conditions and consequently, by the available type of vegetation (e.g.

594 Schulze and Michaelis, 1990; Fleck et al., 2001). In Permian coals, the

595 dominance of tetracyclic diterpenoids, and in particular phyllocladane

596 and kaurane isomers has been related to the pteridosperm Glossopteris,

597 while a predominance of tricyclic terpanes (e.g. isopimarane, rimuane,

598 fichtellite) can particularly indicate a Medullosan pteridosperm input

599 (Noble, 1986). A predominance of kaurane has been also observed in

600 Late Carboniferous rocks (Fabianska et al., 2003) whereas 
601 phyllocladane isomers are more predominant in Lower Carboniferous

602 rocks (Viséan; Disnar and Harouna, 1994).

603 Following the observations of Noble (1986), the abundance of

604 tetracyclic phyllocladanes and kauranes compared to the tricyclic

605 abietane in our coals (Fig. 12) would point to a contribution of non-

606 Medullosan pteridosperms. This is consistent with the spore content of

607 these coals (Spinner and Clayton, 1973), and the described megaflora of

608 Glenarbuck and Pettycur (Scott et al., 1984). In addition, the

609 abundance of ent-beyerane compared to ent-kaurane has been linked to

610 a considerable contribution of Cordaites in late Carboniferous coals

611 from France and Germany (e.g. Schulze and Michaelis, 1990; Vliex et

612 al., 1994; Fleck et al., 2001; Auras et al., 2006). According to these

613 previous studies, the low abundance of ent-beyerane in the Scottish

614 coals can therefore indicate the absence of Cordaites input. This agrees

615 with an absence of Cordaites contribution in the palynological record

616 (Spinner, 1969; Spinner and Clayton, 1973; Scott et al., 1984), and the

617 absence of the arborane/fernane derivatives MATH, MAPH DAPH1 and

618 DAPH2 which have been recently suggested to be of Cordaites origin

619 (Auras et al., 2006).

620 Similarly, abietane, retene, tetrahydroretene, bisnorsimonellite and

621 simonellite (Figs. 13 and 20) have been widely accepted as conifer

622 biomarkers (van Aarssen et al., 2000; Hautevelle et al., 2006). Actually,

623 abietic acid, the major constituent of conifer resin, has been often

624 considered as the biological precursor for retene and its related 
625 aromatic compounds (van Aarssen et al., 2000; Hautevelle et al., 2006).

626 However, most of these compounds, except abietane and

627 bisnorsimonellite, have been recently identified in upper Silurian to

628 lower Devonian sediments and are supposedly associated with early

629 Palaeozoic bryophytes (Romero-Sarmiento et al., 2010). Following Ellis

630 et al. (1996), the higher abundance of alkylphenanthrene compounds

631 compared to isohexylalkylnaphthalenes in the Scottish coals (Fig 13

632 and 19) could indicate a resin acid source. The presence of resinite

633 macerals in both analysed samples (Fig. 4), though in low abundance,

634 gives support to this interpretation. The hypothesis that abietic acid

635 synthesis had already evolved in early land plants, prior to the

636 emergence of true conifers (Romero Sarmiento et al., 2010) gains

637 therefore support with this observation. Similarly, Bray and Anderson

638 (2009) concluded that biosynthetic mechanisms specific to angiosperms

639 had already appeared in the Late Carboniferous, far before the

640 emergence of true angiosperms. 2-Methylretene is commonly associated

641 with retene; it is only known from Permian and younger sediments and

642 considered a conifer biomarker (Bastow et al., 2001). The diaromatic

643 tricyclic totarane and sempervirane also typically co-occur with retene

644 and related hydrocarbons. These biomarkers typically derive from a

645 restricted number of conifer families: mostly Podocarpaceae and

646 Cupressaceae (Otto and Wilde, 2001; Cox et al., 2007), though the

647 totarane skeleton has been also observed in some angiosperms (e.g. 
648 Pinto et al, 1995; Clarkson et al., 2003) and a bryophyte (e.g. Wu and 649 Jong, 2001).

650 In summary, most of the aliphatic and aromatic terrestrial

651 biomarkers observed in the Scottish coals have been related to conifer

652 families (Table 6). The oldest report of conifer megafossils is in the Late

653 Carboniferous (Westphalian B/Late Bashkirian; Scott, 1974) and the

654 oldest occurrence of conifer-related saccate pollens is Early Bashkirian

655 (Zhou, 1994), so that our coals predate the evolution of conifers. Other

656 precursor(s) must therefore be proposed to explain the presence of

657 "conifer biomarkers" in the Viséan Scottish coals. Cordaites are closely

658 related to conifers and have been previously proposed as a source of

659 supposedly typical conifer biomarkers (e.g. Disnar and Harouna, 1994).

660 However, no data support the presence of Cordaites in the flora that

661 contributed to our Scottish coals. An alternative origin for these

662 compounds therefore must be found within the Viséan Scottish flora

663 which was dominated by arborescent or sub-arborescent lycopsids

664 (Lepidodendrales and Isoetales) with a contribution from ferns,

665 sphenopsids and lyginopteridacean pteridosperms. Most of these groups

666 of plants are extinct (Taylor et al., 2009), so that direct comparison with

667 present-day plants is not possible. Pteridosperms are the closest

668 relatives to conifers identified in the Scottish Viséan coals (Taylor et al.,

669 2009), and therefore could have provided the "conifer biomarkers".

670 From the palynological content, pteridosperms were not dominant in

671 the flora of the studied coals (Spinner, 1969; Spinner and Clayton, 
672 1973); a palynological bias is possible, so that pteridosperm biomass

673 would be underestimated in the palynological content (e.g. Phillips et

674 al., 1985; Dimitrova et al., 2005). Pteridosperms, in particular,

675 produced resin (Taylor et al., 2009) and could be at the origin of the

676 resinous secretions observed in our coal samples (Fig. 4C).

677 Lyginopteridacean pteridosperms probably appeared in the latest

678 Devonian (Taylor et al., 2009) but were preceded in the Middle Devonian

679 by progymnosperms, which could therefore be considered for the origin

680 of the "conifer biomarkers" observed in middle Devonian coals (Sheng et

681 al. 1992; Kashirtsev et al., 2010). Progymnosperms, however, were

682 neither described in Chinese nor in Russian Middle Devonian coals

683 (Volkova, 1994; Yi et al., 2007). An alternative source for the "conifer

684 biomarkers" are the arborescent lycopsids (Lepidodendrales) since

685 palynologically, these plants dominated the Scottish flora (Spinner,

686 1969; Spinner and Clayton, 1973). Lepidodendrales already existed

687 during the Devonian (Taylor et al., 2009) and a recent palaeobotanical

688 study showed that the Middle Devonian Chinese coals were dominated

689 by Lepidodendrales and Protolepidodendrales (Yi et al., 2007). From

690 these observations, arborescent lycopsids appear as another likely

691 source for the so-called typical conifer biomarkers.

692

693 6. Conclusions

694 Numerous land-plant biomarkers have been identified in the

695 aliphatic and aromatic fraction of the extracts of Early Carboniferous 
696 coals from Scotland. Among these compounds, several have been

697 classically considered to be conifer-derived. However, micro and

698 macrofossil evidence for conifers does not go further back than the

699 Upper Carboniferous while palynological and palaeobotanical data

700 indicate that these coals mainly derive from arborescent lycopsid

701 (Lepidodendrales)-dominated forest. This discrepancy between the lipid

702 and other fossil records leads to the following hypotheses:

703 1. Conifers had evolved already in the Early Carboniferous and this 704 has now been evidenced with lipids.

705 2. The metabolic pathways giving rise to the observed biomarkers

706 had evolved already in the Early Carboniferous in plants which 707 are related to the conifers.

708 3. The identified biomarkers are derived from terrestrial plants 709 tetrahydroretene - which are generally related to conifers - could also

714 derive from the degradation of kaurane-type compounds synthesised by

715 the early bryophytes. The Lower Carboniferous Scottish coals can be 716 related to a flora dominated by arborescent lycopsids in conjunction

717 with some ferns, sphenopsids and pteridosperms. Among these plants

718 which are presently extinct, pteridosperms, which are relatively closely

719 related to conifers, and arborescent lycopsids, which are not related to 
conifers, appear as the best possible sources for the "typical conifer"

721 biomarkers. Therefore hypotheses 2 and 3 seem the most likely at

722 present.

723

724 Acknowledgements

725

The authors acknowledge financial support from the "ECLIPSE II and INSU 2009 - Terrestrialization" grant from the INSU department of

727 CNRS. Thanks are extended to Dr. Charles Wellman (Department of 728 Animal and Plant Sciences, University of Sheffield, U.K.) for guidance 729 and assistance to M.V. during field work; this latter was funded by an 730 exchange grant from "EGIDE Programme d'Actions Intégrées franco731 britanniques ALLIANCE" of the British Council and the Ministère des 732 Affaires Étrangères of France, which is also gratefully acknowledged. M-

733 F. R-S. acknowledges receipt of a scholarship (No. E07D402105VE)

734 from the Programme Alßan. G. J. M.V. benefited from a position as 735 invited professor at the Universite Lille 1 (France) and a Heisenberg 736 Stipend by the German Science Foundation (DFG). The authors are 737 grateful to François Baudin (Université Paris 6) for performing the Rock738 Eval and LECO analyses and to Brigitte Meyer-Berthaud (CNRSUMR0931 AMAP) for helpful discussions in palaeobotany. This is a

740 contribution to the ANR project "Global Perspectives on the

741 Terrestrialization Process”. The editor Finn Surlyk, Jørgen A. Bojesen-

742 Koefoed, and an anonymous reviewer are acknowledged for constructive 743 comments on the manuscript. 


\section{References}

746

Achari, R.G., Shaw, G., Holleyhead, R., 1973. Identification of ionene and other carotenoid degradation products from the pyrolysis of sporopollenins derived from some pollen exines, a spore coal and the Green River shale. Chemical Geology 12, 229 - 234.

Alexander, R., Kagi, R.I., Rowland, S.J., Sheppard, P.N., Chirila, T.V., 1985. The effects of thermal maturity on distribution of dimethylnaphthalenes and trimethylnaphthalenes in some ancient sediments and petroleums. Geochimica et Cosmochimica Acta 49, $385-395$

Armstroff, A., Wilkes, H., Schwarzbauer, J., Littke, R, Horsfield, B., 2006. Aromatic hydrocarbon biomarkers in terrestrial organic matter of Devonian to Permian age. Palaeogeography, Palaeoclimatology, Palaeoecology, 240, $253-274$.

Arouri, K.R., Greenwood, P.F., Walter, M.R., 2000. Biological affinities of Neoproterozoic acritarchs from Australia: microscopic and chemical characterisation Organic Geochemistry 31, 75 - 89

Asakawa, Y., 2004. Chemosystematics of the Hepaticae. Phytochemistry $65,623-669$

Auras, S., Wilde, V., Scheffler, K., Hoernes, S., Kerp, H., Püttmann, W., 2006. Aromatized arborane/fernane hydrocarbons as biomarkers for Cordaites. Naturwissenschaften 93, $616-621$. 
767 Bastow, T., Alexander, R., Sosrowidjojo, I. B., Kagi, R.I., 1998.

768

769

770

771

772

773

774

775

776

777

778

779

780

781

782

783

784

785

786

787

788

789

790

Pentamethylnaphthalenes and related compounds in sedimentary organic matter. Organic Geochemistry 28, 585 - 595

Bastow, T., Singh, R., Van Aarssen, B., Alexander, R., Kagi, R. 2001. 2methylretene in sedimentary material: a new higher plant biomarker. Organic Geochemistry 32: 1211 - 1217.

Bechtel, A., Sachsenhofer, R.F., Zdravkov, A., Kostova, I., Gratzer, R., 2005. Influence of floral assemblage, facies and diagenesis on petrography and organic geochemistry of the Eocene Bourgas coal and the Miocene Maritza-East lignite (Bulgaria). Organic Geochemistry 36, $1498-1522$.

Bray, E.E., Evans, E.D., 1961. Distribution of $n$-paraffins as a clue to recognition of source beds. Geochimica et Cosmochimica Acta 22, 2 $-15$.

Bray, P.S., Anderson, K.B., 2009. Identification of Carboniferous (320 Million Years Old) Class Ic Amber. Science 326, 132 - 134.

Brocks, J.J., Logan, G.A., Buick, R., Summons, R.E., 1999. Archean molecular fossils and the early rise of Eukaryotes. Science 285, $1033-1036$.

Brocks, J.J., Buick, R., Summons, R.E., Logan, G.A., 2003. A reconstruction of Archean biological diversity based on molecular fossils from the 2.78 to 2.45 billion-year-old Mount Bruce Supergroup, Hamersley Basin, Western Australia. Geochimica et Cosmochimica Acta 67, 4321 - 4335. 
791 Brocks, J.J., Love, G.D., Summons, R.E., Knoll, A.H., Logan, G.A.,

792

793

794

795

796

797

798

799

800

801

802

803

804

805

806

807

808

809

810

811

812

813

Bowden, S.A., 2005. Biomarker evidence for green and purple

sulphur bacteria in a stratified Palaeoproterozoic sea. Nature 437, $866-870$

Chopra, R.N., Kumra, K.P., 1988. Biology of Bryophytes. John Wiley \& Sons, New York, 350 p.

Clarkson, C., Campbell, W.E., Smith, P., 2003. In vitro antiplasmodial activity of abietane and totarane diterpenes isolated from Harpagophytum procumbens (devil's claw). Planta Medica 69, 720 724.

Cox, R.E., Yamamoto, S., Otto, A., Simoneit, B.R.T., 2007. Oxygenated di- and tricyclic diterpenoids of southern hemisphere conifers. Biochemical Systematics and Ecology 35, 342 - 362.

Day, W.C., Erdman, J.G., 1963. Ionene: a thermal degradation product of $\beta$-carotene. Science 141, 808.

del Río, J. C., Garcia-Molla, J., González-Vila, F. J., Martin, F., 1994. Composition and origin of the aliphatic extractable hydrocarbons in the Puertollano (Spain) oil shale. Organic Geochemistry, 21, 897 909.

DiMichele W.A., 1980. Paralycopodites Morey \& Morey, from the Carboniferous of Euramerica — A Reassessment of Generic Affinities and Evolution of "Lepidodendron" brevifolium Williamson. American Journal of Botany 67, 1466 - 1476. 
814 DiMichele, W.A., Phillips, T.L., 1994. Paleobotanical and paleoecological 815 constraints on models of peat formation in the Late Carboniferous 816 of Euramerica. Palaeogeography, Palaeoclimatology, Palaeoecology $817 \quad 106,39-90$.

818 Dimitrova, T.K., Cleal, C.J., Thomas, B.A., 2005. Palynology of late 819 Westphalian-early Stephanian coal-bearing deposits in the eastern $820 \quad$ South Wales Coalfield. Geological Magazine 142, $809-821$.

821 Disnar, J.R., Harouna, M., 1994. Biological origin of tetra-cyclic 822 diterpanes, $n$-alkanes and other biomarkers found in Lower

825 Dzou, L.I.P., Noble, R.A., Senftle, J.T., 1995. Maturation effects on 826 Carboniferous Gondwana coals (Niger). Organic Geochemistry 21, $143-152$. absolute biomarker concentration in a suite of coals and associated vitrinite concentrates. Organic Geochemistry 23, 681 - 697.

Eble, C.F., 1996. Lower and lower Middle Pennsylvanian coal palynofloras, southwestern Virginia. International Journal of Coal Geology 31, $67-113$.

831 Eglinton, G., Hamilton, R.J., 1967. Leaf epicuticular waxes. Science $832 \quad 156,1322-1335$.

833 Eglinton, T.I., Eglinton, G., 2008. Molecular proxies for 834 paleoclimatology. Earth and Planetary Science Letters 275, 1 - 16. 835 Eigenbrode, J.L., Freeman, K.H., Summons, R.E., 2008. Methylhopane 836 biomarker hydrocarbons in Hamersley Province sediments provide 
evidence for Neoarchean aerobiosis. Earth and Planetary Science Letters 273, $323-331$.

839 Ellis, L., Singh, R., Alexander, R., Kagi, R., 1996. Formation of isohexyl alkylaromatic hydrocarbons from aromatization-rearrangement of terpenoids in the sedimentary environment: A new class of biomarker. Geochimica and Cosmochimica Acta 60, 4747 - 4763.

Espitalié, J., Deroo, G., Marquis, F., 1986. La pyrolyse Rock-Eval et ses applications. Revue de l'Institut Français du Pétrole 41, 73 - 89.

Fabianska, M. J., Bzowska, G., Matuszewska, A., Racka, A., Skret, U., 2003. Gas chromatography-mass spectrometry in geochemical investigation of organic matter of the Grodziec Beds (Upper $63,63-91$

851

852 355.

853 Fleck, S., Michels, R., Izart, A., Elie, M., Landais, P., 2001. Palaeoenvironmental assessment of Westphalian fluvio-lacustrine deposits of Lorraine (France) using a combination of organic geochemistry and sedimentology. International Journal of Coal Geology 48, $65-88$.

858 Fleck, S., Michels, R., Ferry, S., Malartre, F., Elion, P., Landais, P., 859 2002. Organic geochemistry in a sequence stratigraphic framework. 
The siliciclastic shelf environment of Cretaceous series, SE France.

862 Fowler, M.G., Goodarzi, F., Gentzis, T., Brooks, P.W., 1991. Hydrocarbon potential of Middle and Upper Devonian coals from Melville Island, Arctic Canada. Organic Geochemistry 17, 681 694.

George, S.C., 1992. Effect of igneous intrusion on the organic geochemistry of a siltstone and an oil shale horizon in the Midland Valley of Scotland. Organic Geochemistry 18, 705 - 723.

Glasspool, I.J., Hemsley, A.R., Scott, A.C., Golitsyn, A., 2000. Ultrastructure and affinity of Lower Carboniferous megaspores from the Moscow Basin, Russia. Review of Palaeobotany and Palynology 109, $1-31$.

Hautevelle, Y., Michels, R., Malartre, F., Trouiller, A., 2006. Vascular plant biomarkers as proxies for palaeoflora and palaeoclimatic changes at the Dogger/Malm transition of the Paris Basin (France). Organic Geochemistry 37, $610-625$.

Huang, W.-Y., Meinschein, W.G., 1979. Sterols as ecological indicators. Geochimica et Cosmochimica Acta 43,739 - 745 . and Co., New York.

881 Iinuma, Y., E. Brüggemann, T. Gnauk, K. Müller, M. O. Andreae, G. of biomass burning particles: The combustion of selected European 
conifers, African hardwood, savanna grass, and German and Indonesian peat, Journal of Geophysical Research, 112, D08209.

886

887

888

889

890

891

892

893

894

895

896

897

898

899

900

901

902

903

904

905

906

International Committee of Coal Petrology (ICCP), 1975. International Handbook for Coal Petrology, 2nd ed., CNRS, Paris.

Izart, A., Sachsenhofer, R. F., Privalov, V. A., Elie, M., Panova, E. A., Antsiferov, V. A., Alsaab, D., Rainer, T., Sotirov, A., Zdravkov, A., Zhykalyak, M. V., 2006. Stratigraphic distribution of macerals and biomarkers in the Donets Basin: Implications for paleoecology, paleoclimatology and eustacy. International Journal of Coal Geology, 66, $69-107$.

Jiang, C., Alexander, R., Kagi, R.I., Murray, A. P., 1998. Polycyclic aromatic hydrocarbons in ancient sediments and their relationships to palaeoclimate. Organic Geochemistry 29, 1721 1735.

Kashirtsev, V.A., Moskvin, V.I., Fomin, A.N., Chalaya, O.N., 2010. Terpanes and steranes in coals of different genetic types in Siberia. Russian Geology and Geophysics 51, $404-411$.

Murchison D. G., Raymond A. C., 1989. Igneous activity and organic maturation in the Midland Valley of Scotland. International Journal of Coal Geology 14, 47-82.

Niklas, K.J., 1976a. The chemotaxonomy of Parka decipiens from the lower old red sandstone, Scotland (U.K.). Review of Palaeobotany and Palynology 21, $205-217$. 
907

908

909

910

911

912

913

914

915

916

917

918

919

920

921

922

923

924

925

926

927

928

929

930

Niklas, K.J., 1976b Chemotaxonomy of Prototaxites and evidence for possible terrestrial adaptation. Review of Palaeobotany and Palynology 22, $1-17$.

Niklas, K.J., Chaloner, W.G., 1976. Chemotaxonomy of some problematic palaeozoic plants. Review of Palaeobotany and Palynology 22, $81-104$

Niklas, K.J., Pratt, L.M., 1980. Evidence for lignin-like constituents in early silurian (llandoverian) plant fossils. Science 209, 396 - 397.

Noble, R. A., 1986. A geochemical study of bicyclic alkanes and diterpenoid hydrocarbons in crude oils, sediments and coals. Thesis. The University of Western Australia. 398 p.

Noble, R. A., Alexander, R., Kagi R.I., Knox, J., 1985. Tetracyclic diterpenoid hydrocarbons in some Australian coals, sediments and crude oils. Geochimica and Cosmochimica Acta 49, $2141-2147$.

Noble, R. A., Alexander, R., Kagi R.I., 1987. Configurational isomerization in sedimentary bicyclic alkanes. Organic Geochemistry $11,151-156$.

Olcott, A.N., 2007. The utility of lipid biomarkers as paleoenvironmental indicators. Palaios 22, $111-113$.

Opluštil, S, Bek, J, Schultka, S, 2009. Re-examination of the genus Omphalophloios White, 1898 from the Upper Silesian Coal Basin. Bulletin of Geosciences 85, $39-52$.

Oros, D.R., Simoneit, B.R.T., 2001a. Identification and emission factors of molecular tracers in organic aerosols from biomass burning Part 

1544.

933 Oros, D.R., Simoneit, B.R.T., 2001b. Identification and emission factors 934 of molecular tracers in organic aerosols from biomass burning Part 2. Deciduous trees. Applied Geochemistry 16, 1545 - 1565.

Oros, D.R., Abas, M.R.b., Omar, N.Y.M.J., Rahman, N.A., Simoneit, B.R.T., 2006. Identification and emission factors of molecular tracers in organic aerosols from biomass burning: Part 3. Grasses. Applied Geochemistry 21, $919-940$.

Otto, A., Simoneit, B.R.D., 2001. Chemosystematics and diagenesis of terpenoids in fossil conifer species and sediment from the Eocene Zeitz Formation, Saxony, Germany. Geochimica et Cosmochimica Acta 65, $3505-3527$.

944 Otto, A., Wilde, V., 2001. Sesqui-, di- and triterpenoids as chemosystematic markers in extant conifers - A review. The Botanical Review 67, $141-238$.

947 Otto, A., Walther, H., Püttmann, W., 1997. Sesqui- and diterpenoid 948 biomarkers preserved in Taxodium-rich Oligocene Oxbow Lake 949 Clays, Weisselster basin, Germany. Organic Geochemistry 26, 105 $950-115$

951 Otto, A., Simoneit, B.R.T., Wilde, V., Kunzmann, L., Püttmann, W., 952 2002. Terpenoid composition of three fossil resins from Cretaceous 953 and Tertiary conifers. Review of Palaeobotany and Palynology 120, $954 \quad 203-215$. 
955 Ourisson, G., Albrecht, P., Rohmer, M., 1979. The hopanoids.

956 Palaeochemistry and biochemistry of a group of natural products.

$957 \quad$ Pure and Applied Chemistry 51, $709-729$.

958 Peters, K.E., Moldowan, J.M., 1993. The Biomarker Guide: Interpreting

959 molecular fossils in petroleum and ancient sediments. Prentice

960 Hall, Englewood Cliffs, New Jersey. 363 p.

961 Peters, K.E., Walters, C.W., Moldowan, J.M., 2005. The Biomarker

962 Guide. Cambridge University Press. Cambridge -706 p.

963 Philp, R.P., 1985. Fossil Fuel Biomarkers Applications and Spectra.

964 Elsevier, Amsterdam.

965 Phillps, T., 1979. Reproduction of heterosporous arborescent lycopods

966 in the Mississippian - Pennsylvanian of Euramerica. Review of

$967 \quad$ Palaeobotany and Palynology 27, $239-289$.

968 Pinto A.C., Zocher D.H.T., Rezende C.M., Gottlieb H.E., 1995. A new

969 diterpene with a totarane skeleton from Vellozia flavicans. Natural

$970 \quad$ Product Research 6, $209-213$.

971 Radke, M., Willsch, H., Leythaeuser, D., 1982. Aromatic components of

972 coal: relation of distribution pattern to rank. Geochimica et

$973 \quad$ Cosmochimica Acta 46, $1831-1848$.

974 Radke, M., Willsch, H., Welte, D.H., 1986. Maturity parameters based

975 on aromatic hydrocarbons: influence of the organic matter type.

$976 \quad$ Organic Geochemistry 10, $51-63$. 
977 Radke, M., Vriend, S. P., Ramanampisoa, L. R., 2000.

978

979

980

981

982

983

984

985

986

987

988

989

990

991

992

993

994

995

996

997

998

999

1000 Alkyldibenzofurans in terrestrial rocks: Influence of organic facies and maturation. Geochimica et Cosmochimica Acta 64, 275 - 286.

Rampen, S.W, Abbas, B.A., Schouten, S., Sinninghe Damsté, J.S., 2010. A comprehensive study of sterols in marine diatoms (Bacillariophyta): Implications for their use as tracers for diatom productivity. Limmonology and Oceanography 55, 91 - 105.

Romero-Sarmiento, M.F., Riboulleau, A., Vecoli, M., Versteegh., G., 2010. Occurrence of retene in upper Silurian - Lower Devonian sediments from North Africa: Origin and implications. Organic Geochemistry 41, $302-306$.

Schulze, T., Michaelis, W., 1990. Structure and origin of terpenoid hydrocarbons in some German coals. Organic Geochemistry 16, $1051-1058$.

Scott, A., 1974. The earliest conifer. Nature 251, $707-708$.

Scott, A.C., Hemsley, A. R., 1996. Palaeozoic megaspores. Chapter 18G. In: Jansonius, J. \& McGregor, D.C. (ed.) Palynology: principles and applications. American Association of Stratigraphic Palynologists Foundation, Vol. 2, $629-639$.

Scott, A.C., Jones, T.P., 1994. The nature and influence of fire in Carboniferous ecosystems. Palaeogeography, Palaeoclimatology, Palaeoecology 106, $91-112$.

Scott, A.C., Galtier, J., Clayton, G., 1984. Distribution of anatomicallypreserved floras in the Lower Carboniferous in Western Europe. 
Transaction of the Royal Society of Edinburgh: Earth Sciences 75, $311-340$.

Seifert, W.K., Moldowan, J.M., 1978. Applications of steranes, terpanes and monoaromatics to the maturation, migration and source of crude oils. Geochimica et Cosmochimica Acta 42, 77 - 95.

1006

Seifert, W.K., Moldowan, J.M., 1980. The effect of thermal stress on

1007

1008 source rock quality as measured by hopane stereochemistry. In: Douglas, A.G., Maxwell, J.R. (Eds.), Advances in Organic Geochemistry, 1979. Pergamon Press, 229 - 237.

Seifert, W.K., Moldowan, J.M., 1986. Use of biological markers in petroleum exploration. In: Johns, R.B. (Ed.), Biological Markers in the Sedimentary Record, Methods in Geochemistry and Geophysics, vol. 24. Elsevier, Amsterdam, pp. 261-290.

Sheng, G., Simoneit, B. R. T., Leif, R. N., Chen, X., Fu, J., 1992. Tetracyclic terpanes enriched in Devonian cuticle humic coals. Fuel, 71, $523-532$.

Shiea, J., Brassell, S.C., Ward, D.M., 1990. Mid-chain branched monoand dimethyl alkanes in hot spring cyanobacterial mats: a direct biogenic source for branched alkanes in ancient sediments? Organic Geochemistry 15, $223-231$.

Simoneit, B. R. T., Grimalt, J. O., Wang, T. G., Cox, R. E., Hatcher, P. G., Nissenbaum, A., 1986. Cyclic terpenoids of contemporary resinous plant detritus and of fossil woods, ambers and coals. Organic Geochemistry 10, $877-889$. 
1025 Spinner, E., 1969. Megaspore assemblages from Viséan deposits at Dunbar, East Lothian, Scotland. Palaeontology 12, 441 - 458.

1027 Spinner, E., Clayton, G., 1973. Viséan spore assemblages from

$1028 \quad$ Skateraw, East Lothian, Scotland. Pollen et Spores XV, $139-165$.

1029 Stefanova, M., Markova, K., Marinov, S., Simoneit, B.R.T., 2005. Molecular indicators for coal-forming vegetation of the Miocene Chukurovo lignite, Bulgaria. Fuel 84, 1830 - 1838.

Talyzina, N.M., Moldowan, J.M., Johannisson, A., Fago, F.J., 2000. Affinities of Early Cambrian acritarchs studied by using microscopy, fluorescence flow cytometry and biomarkers. Review of Palaeobotany and Palynology 108, $37-53$.

Tissot, B., Welte, D.M., 1984. Petroleum Formation and Occurrence.

Taylor, T.N., Taylor, E.L., Krings, M., 2009. Paleobotany: The Biology Springer-Verlag, Berlin, 699 p. and Evolution of Fossil Plants. Academic Press, 1230 p.

Thomas, B. R., 1969. Organic Geochemistry. Methods and results, chapter Kauri resins- modern and fossil. Springer Verlag, Berlin,

1043 Tuo, J., Philp, R. P., 2005. Saturated and aromatic diterpenoids and

Underhill, J. R., Monaghan, A. A., Browne, M. A. E., 2008. Controls on structural styles, basin development and petroleum prospectivity in 
the Midland Valley of Scotland. Marine and Petroleum Geology 25, $1000-1022$.

1050

1051

1052

1053

1054

1055

1056

1057

1058

1059

1060

1061

1062

1063

1064

1065

1066

1067

1068

1069

1070

van Aarssen, B.K.G, Bastow, T.P., Alexander, R., Kagi, R., 1999. Distributions of methylated naphthalenes in crude oils: indicators of maturity, biodegradation and mixing. Organic Geochemistry 30, $1213-1227$.

van Aarssen, B.K.G., Alexander, R., Kagi, R.I, 2000. Higher plant biomarkers reflect palaeovegetation changes during Jurassic times. Geochimica et Cosmochimica Acta 64, 1417 - 1424.

Ventura, G.T., Kenig, F., Reddy, C.M., Schieber, J., Frysinger, G.S., Nelson, R.K., Dinel, E., Gaines, R.B., Schaeffer, P., 2007. Molecular evidence of Late Archean archaea and the presence of a subsurface hydrothermal biosphere. Proccedings of the National Academy of Sciences 104, $14260-14265$.

Vliex, M., Hagemann, H.W., Püttmann, W., 1994. Aromatized arborane/fernane hydrocarbons as molecular indicators of floral changes in Upper Carboniferous/Lower Permian strata of the SaarNahe Basin, southwestern Germany. Geochimica et Cosmochimica Acta 58, $4689-4702$.

Volkova, I.B., 1994. Nature and composition of the Devonian coals of Russia. Energy and Fuels 8, 1489 - 1493

Wagner, R.H., 1989. A late Stephanian forest swamp with Sporangiostrobus fossilized by volcanic ash fall in the Puertollano 

$-552$.

Waldbauer, J.R., Sherman, L.S., Sumner, D.Y., Summons, R.E., 2009. Late Archean molecular fossils from the Transvaal Supergroup record the antiquity of microbial diversity and aerobiosis. Precambrian Research 169, $28-47$.

Wang, S. J., 1998. The cordaitean fossil plants from Cathaysian area in China. Acta Botanica Sinica 40, 573 - 579.

Wang, T.G., Simoneit, B.R.T., 1990. Organic geochemistry and coal petrology of Tertiary brown coal in the Zhoujing mine, Baise Basin, South China. Fuel 69, $12-20$.

Wu C.-L., Jong J.-R., 2001. A Cyclic Peroxide of Clerodenoic Acid from the Taiwanese Liverwort Schistochila acuminata. Journal of Asian Natural Products Research 3, $241-246$.

Yi, W., Berry, C.M., Shougang, H., Honghe, X., Qiang, F. (2007) The Xichong flora of Yunnan, China: diversity in late Mid Devonian plant assemblages. Geological Journal 42, 339 - 350.

Zhou, Y.X., 1994. Earliest pollen-dominated microfloras from the early Late Carboniferous of the Tian Shan Mountains, NW China: their significance for the origin of conifers and palaeophytogeography. Review of Palaeobotany and Palynology 81, $193-211$. 
1094 Figure captions

1095 Fig. 1. Simplified geologic map showing the outcrop sample positions at

1096 Dunbar (White Sand and Skateraw Bays) in the Midland Valley of

1097 Scotland (modified from Spinner and Clayton, 1973; Underhill et al.,

1098 2008).

1099

1100 Fig. 2. The outcrop geological succession showing alternating

1101 Carboniferous limestones, shales, sandstones and coals (modified from

1102 Spinner and Clayton, 1973).

1103

1104 Fig. 3. Plot of HI vs. $\mathrm{T}_{\max }$ values for Scottish coals (diagram from

1105 Espitalié et al., 1986).

1106

1107 Fig. 4. Photomicrographs of macerals. A) WS-3, reflected natural light.

1108 Vitrinite particles : telocollinite (Vt) and desmocollinite (Vd). B) Same

1109 zone as A, blue light fluorescence emphasizing exinite particles:

1110 fluorescing spores (S) and cuticles (C). C) SKT-E, blue light

1111 fluorescence. Exinite particles: fluorescing spores (S) and resinite (R)

1112 filling conducting canals in a vitrinite particle. D) WS-3, reflected

1113 natural light. Pyrofusinite $(\mathrm{P})$ and spores $(\mathrm{S})$ in a vitrinite (V)

1114 groundmass.

1115 
1116 Fig. 5. Total ion current chromatograms of the aliphatic fraction from

1117 coal extracts. Numbers above symbols denote to carbon number of $n$ -

1118 alkane

1119

1120 Fig. 6. Mass chromatograms $m / z 57$ of aliphatic fractions from coal

1121 samples, showing the distribution of $n$-alkanes, isoprenoids and

1122 branched alkanes. Numbers above symbols indicate carbon number.

1123

1124 Fig. 7. Plot of $\mathrm{Pr} / n-\mathrm{C}_{17}$ vs. $\mathrm{Ph} / n-\mathrm{C}_{18}$ for Scottish coals (diagram from 1125 Hunt, 1995).

1126

1127 Fig. 8. Mass chromatograms $m / z 191$ of aliphatic fractions from coal

1128 samples, showing the distribution of hopanes and moretanes. Numbers

1129 above symbols indicate carbon number. The molecular structure

1130 represents the standard hopane skeleton.

1131

1132 Fig. 9. Mass chromatograms $m / z 217$ of aliphatic fractions from coal

1133 samples, showing the distribution of steroids. Numbers above symbols

1134 indicate carbon number.

1135

1136 Fig. 10. Steroids ternary plot. The contributions of $\mathrm{C}_{27}, \mathrm{C}_{28}$ and $\mathrm{C}_{29}$

1137 steranes were calculated using the peak height of $\alpha \alpha \alpha(20 \mathrm{R})$ and $\alpha \beta \beta$

1138 (20S) isomers on $m / z 217$ fragmentograms. Paleoenvironmental and

1139 source interpretation from Huang and Meinschein (1979). 
1141 Fig. 11. Partial $\mathrm{m} / \mathrm{z} 109+123+179+193$ mass fragmentograms

1142 showing the distribution of bicyclic alkanes $(+)$ in the extracts of

1143 Scottish coals. Peak assignments in Table 3. Numbers denote carbon

1144 number.

1145

1146 Fig. 12. Partial $\mathrm{m} / z 109+123+193+233$ mass fragmentograms

1147 showing the distribution of diterpenoid hydrocarbons (o) in the extracts

1148 of Scottish coals. Peak assignments in Table 4. Numbers denote carbon

1149 number. (A) Mass spectrum of compound identified as $\mathrm{C}_{18}$ tricyclic

1150 hydrocarbon (Peak II).

1151

1152 Fig. 13. Total ion current chromatograms of aromatic fraction from

1153 extracts of two selected coal samples. Peak assignments in Table 5

1154 Abbreviations: MN - methylnaphthalene; EN + DMN - ethyl- and

1155 dimethylnaphthalene; DBF - dibenzofuran; TMN -

1156 trimethylnaphthalene; MDBF - methyldibenzofuran; TeMN -

1157 tetramethylnaphthalene; DMDBF - dimethyldibenzofuran; P -

1158 phenanthrene; PMN - pentamethylnaphthalene; MP -

1159 methylphenanthrene; EP + DMP - ethyl- and dimethylphenanthrene;

1160 PAHs - polycyclic aromatic hydrocarbons; X - contaminant

1161 (polysiloxanes).

1162 
1163 Fig. 14. Partial $\mathrm{m} / z \quad 142+156$ mass fragmentograms showing the

1164 distribution of methyl-; ethyl- and dimethylnaphthalene isomers in the

1165 aromatic fractions of Scottish coals. Abbreviations: MN -

1166 methylnaphthalene; EN - ethylnaphthalene; DMN -

1167 dimethylnaphthalene. Peak assignments in Table 5.

1168

1169 Fig. 15. Partial $\mathrm{m} / \mathrm{z} 170$ mass fragmentograms showing the

1170 distribution of trimethylnaphthalene (TMN) isomers in the aromatic

1171 fractions of Scottish coals.

1172

1173 Fig. 16. Partial $\mathrm{m} / \mathrm{z} 184$ mass fragmentograms showing the

1174 distribution of tretramethylnaphthalene (TeMN) isomers in the aromatic

1175 fractions of Scottish coals.

1176

1177 Fig. 17. Partial $\mathrm{m} / z \quad 178+192$ mass fragmentograms showing the

1178 distribution of phenanthrene (P), anthracene (A), methylphenanthrene

1179 (MP) and methylanthracene (MA) isomers in the aromatic fractions of

1180 Scottish coals.

1181

1182 Fig. 18. Partial $\mathrm{m} / \mathrm{z} 206$ mass fragmentograms showing the

1183 distribution of ethyl- and dimethylphenanthrene isomers in the

1184 aromatic fractions of Scottish coals. Abbreviations: EP -

1185 ethylphenanthrene, DMP - dimethylphenanthrene.

1186 
1187 Fig. 19. Partial $\mathrm{m} / z 155+169+183$ mass fragmentograms showing a

1188 series of $\mathrm{C}_{17}$ to $\mathrm{C}_{19}$ isohexylalkylnaphthalenes in the aromatic fractions

1189 of Scottish coals. Peak assignments in Table 5. Abbreviations: iHMN -

1190 isohexylalkylnaphthalene, PMN - pentamethylnaphthalene, DMP -

1191 dimethylphenanthrene.

1192

1193 Fig. 20. Partial m/z 237 and $\mathrm{m} / \mathrm{z} 223$ mass fragmentograms showing

1194 the distribution of diaromatic tricyclic hydrocarbons in the aromatic

1195 fractions of Scottish coals. Abbreviations: Sim - simonellite, To -

1196 diaromatic tricyclic totarane, Semp - diaromatic tricyclic sempervirane,

1197 Tre - tetrahydroretene. Peak assignments in Table 5. Mass spectra of

1198 the two tentatively identified tetrahydroretene-derived isomers are also

1199 showed shown $\left(\operatorname{Tre}^{1}\right.$ and $\left.\operatorname{Tre}^{2}\right)$.

1200

1201 Table captions

1202 Table 1

1203 Bulk and molecular geochemical parameters from Scottish coals.

1204

1205 Table 2

1206 Petrographic composition and vitrinite reflectance.

1207

1208 Table 3

1209 Bicyclic alkanes identified.

1210 
1211 Table 4

1212 Diterpenoid hydrocarbons identified.

1213

1214 Table 5

1215 Aromatic hydrocarbons identified.

1216

1217 Table 6

1218 Maturity indicators from aromatic fractions of Carboniferous coal

1219 samples.

1220

1221 Table 7

1222 List of target saturated and aromatic land plant biomarkers and their

1223 origin.

1224

1225 Appendix

1226 Mass spectra of unknown compounds (Peak assignments in Tables 2

1227 and 3).

1228 


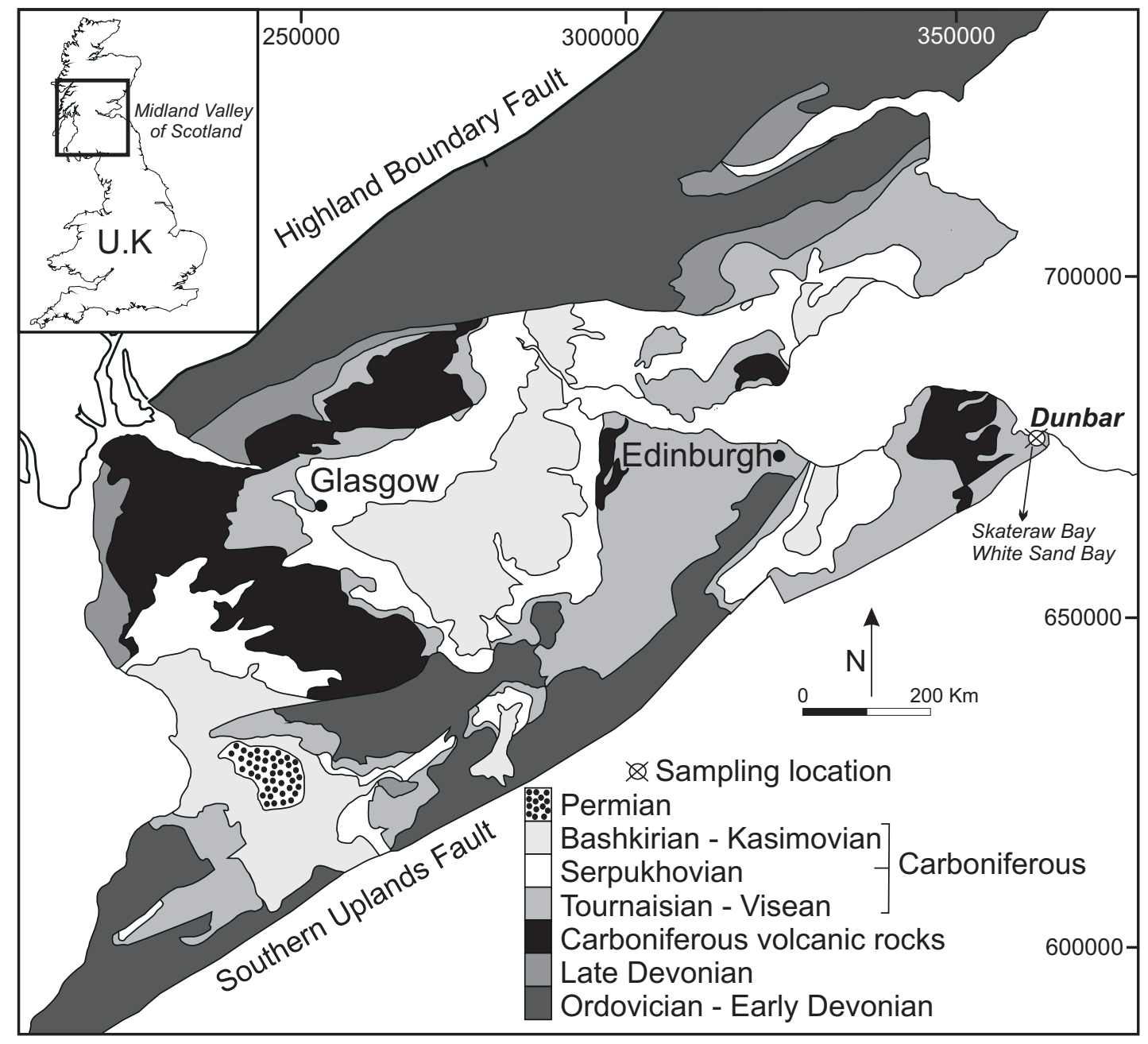




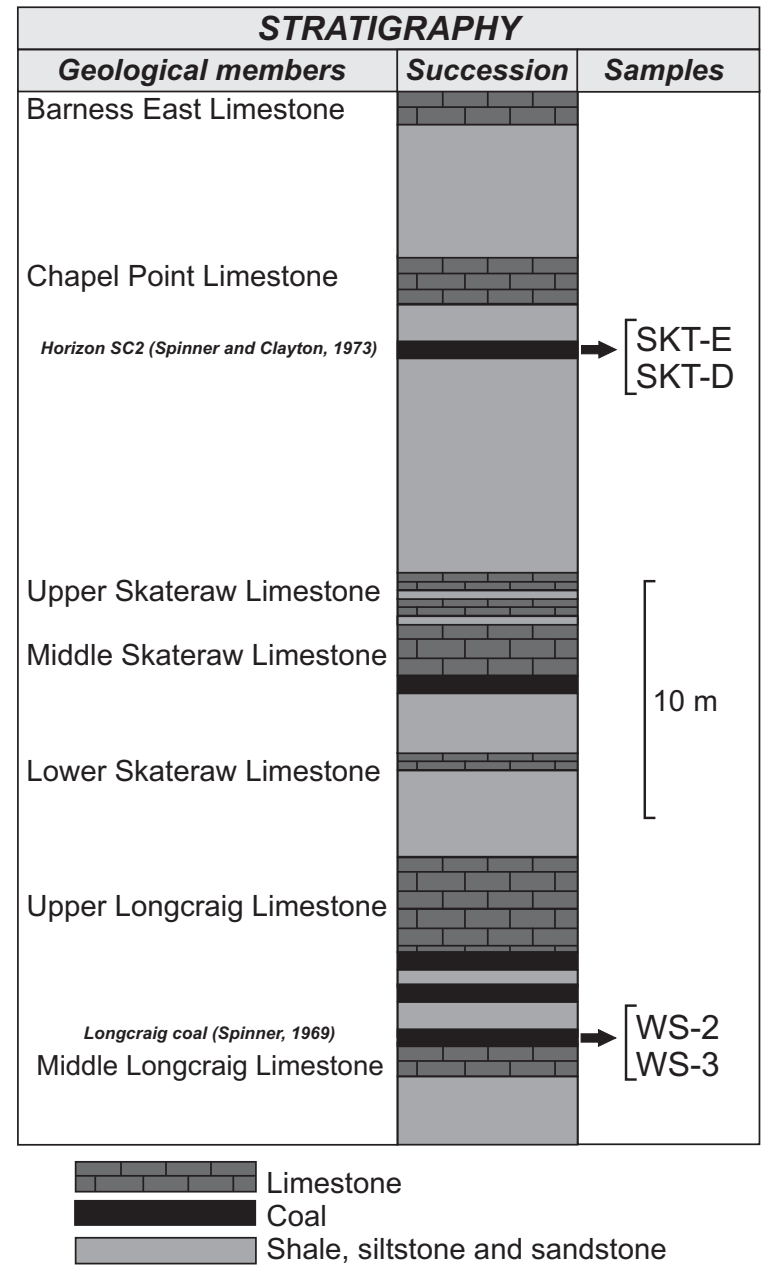




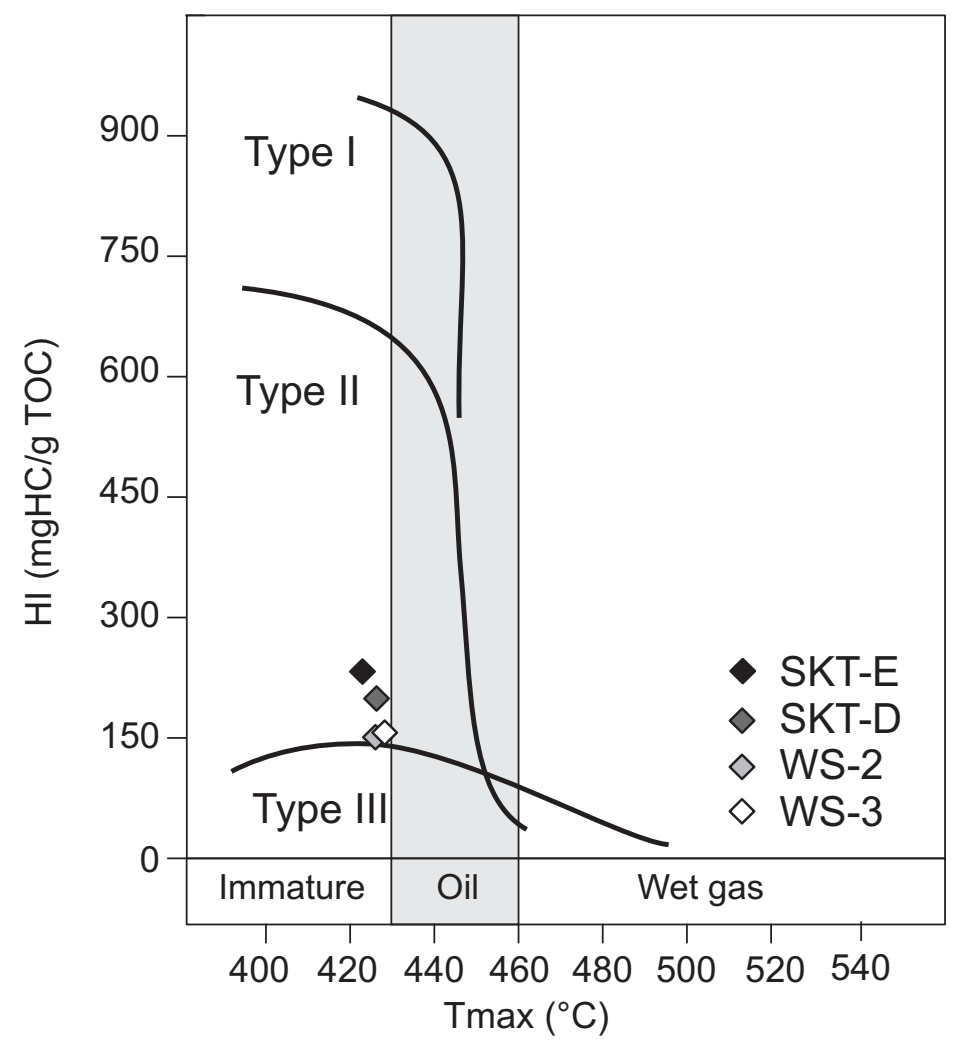



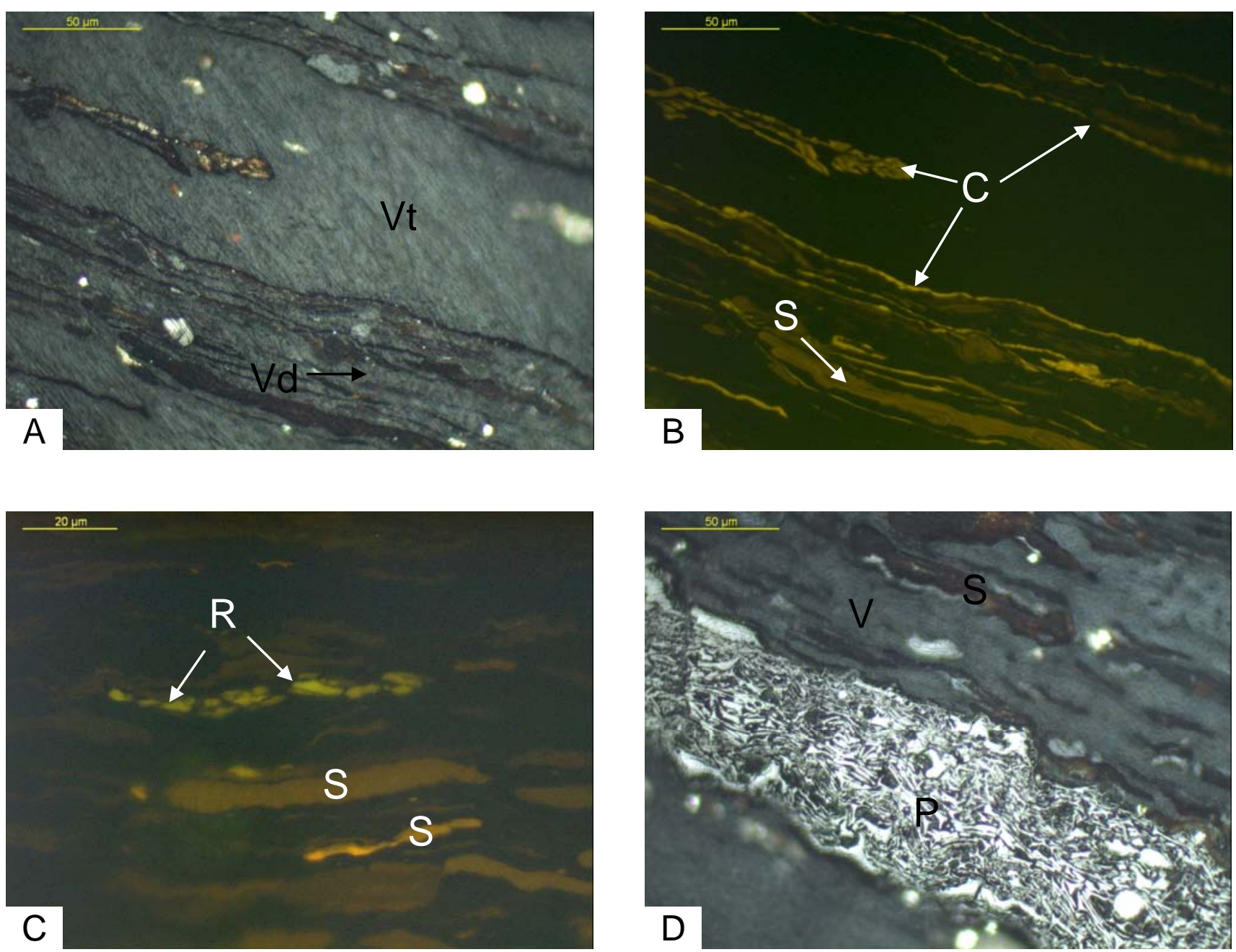

Fig. 4. Photomicrographs of macerals A) WS-3, reflected natural light. Vitrinite particles : telocollinite (Vt) and desmocollinite (Vd). B) Same zone as A, blue light fluorescence emphasizing exinite particles: fluorescing spores (S) and cuticles (C). C) SKT-E, blue light fluorescence. Exinite particles: fluorescing spores $(S)$ and resinite $(R)$ filling conducting canals in a vitrinite particle. D) WS-3, reflected natural light. Pyrofusinite $(P)$ and spores (S) in a vitrinite $(\mathrm{V})$ groundmass. 

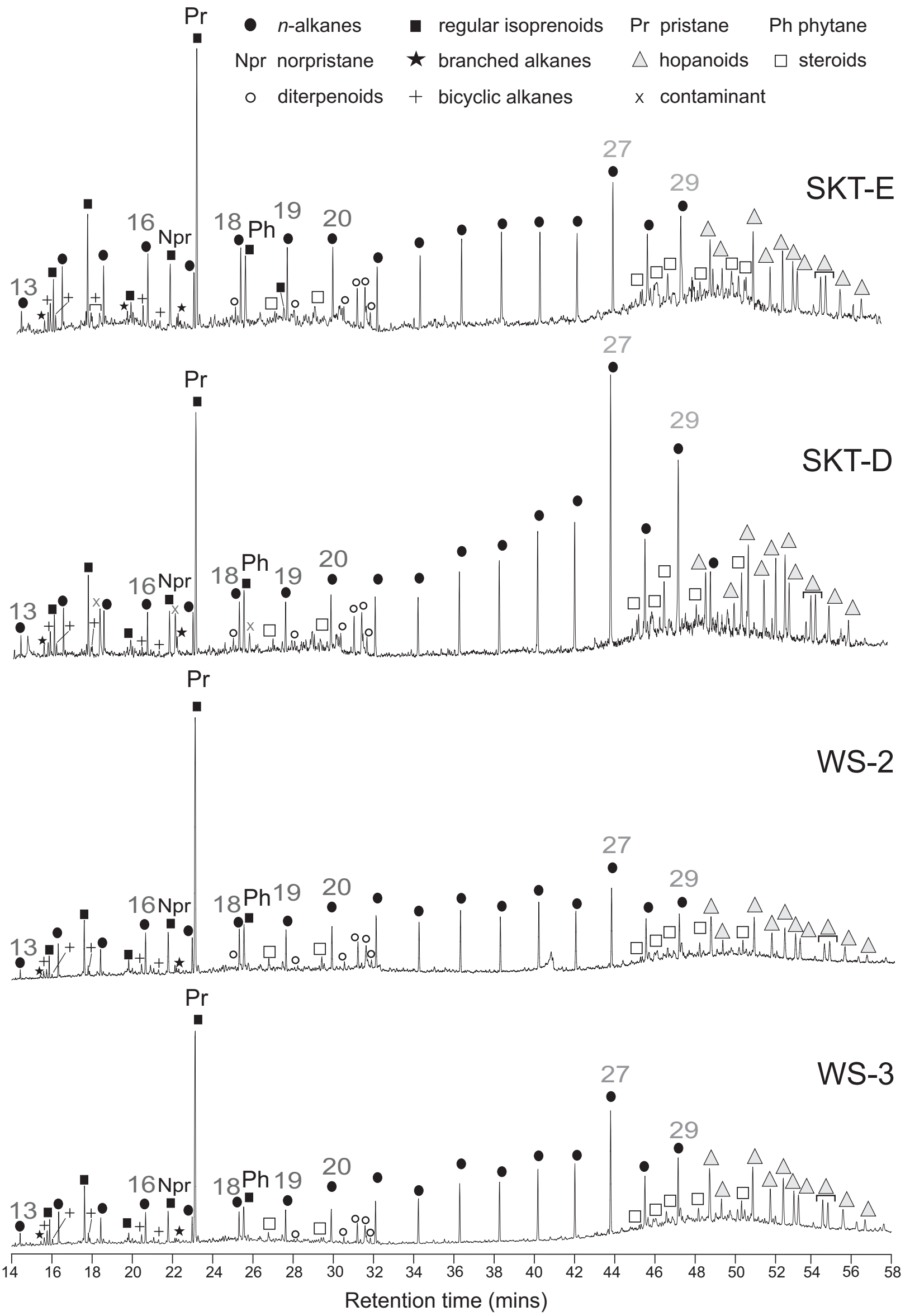


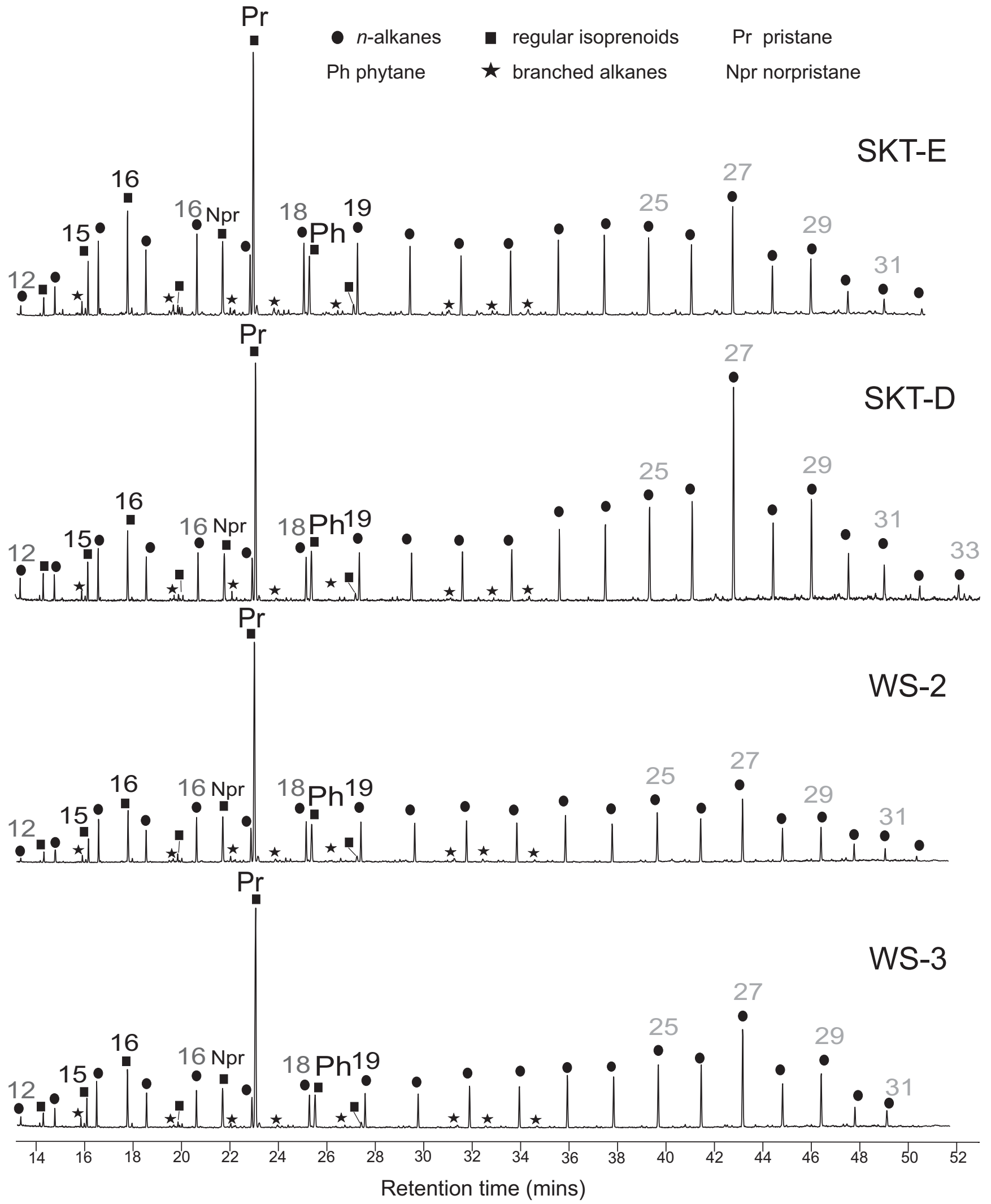




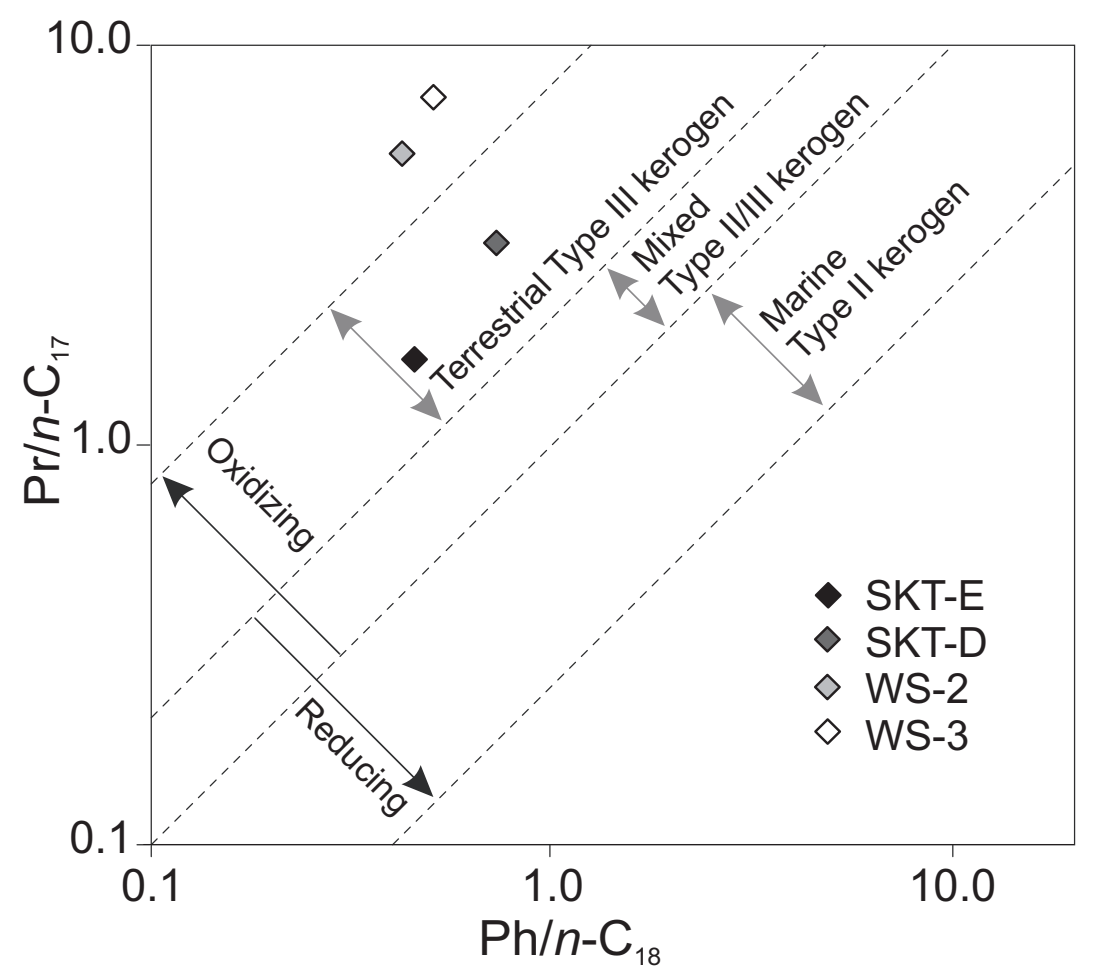



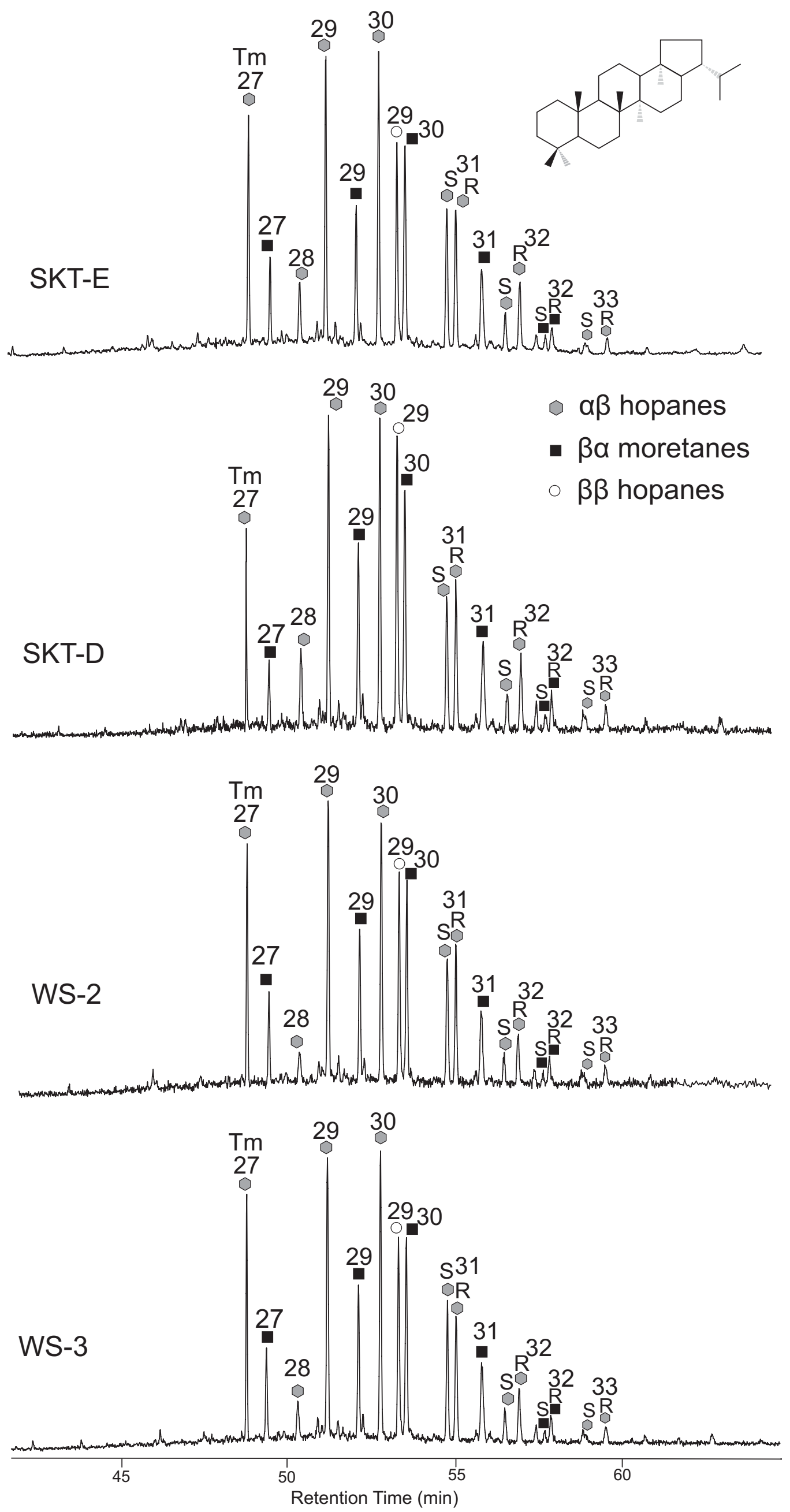

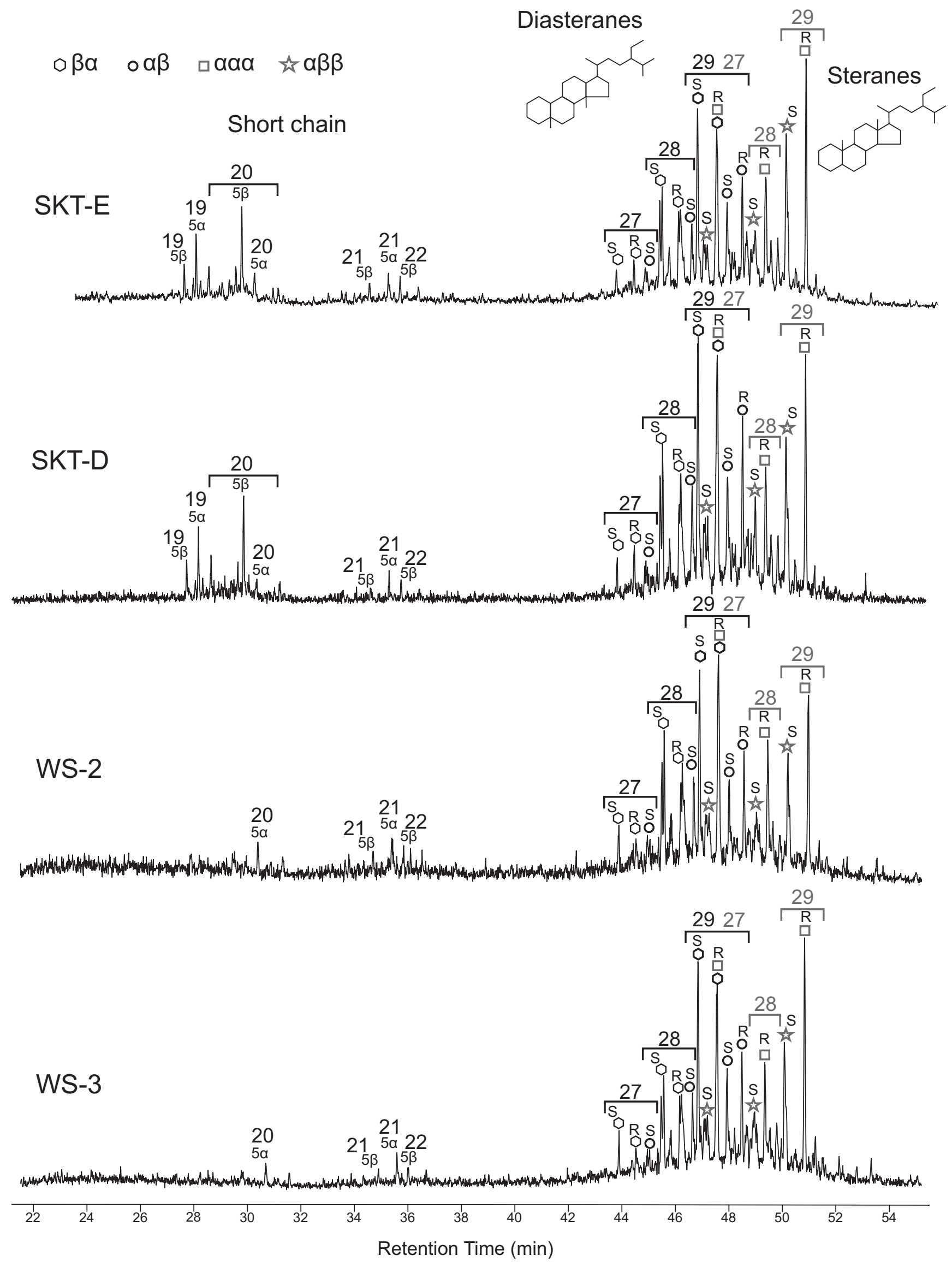


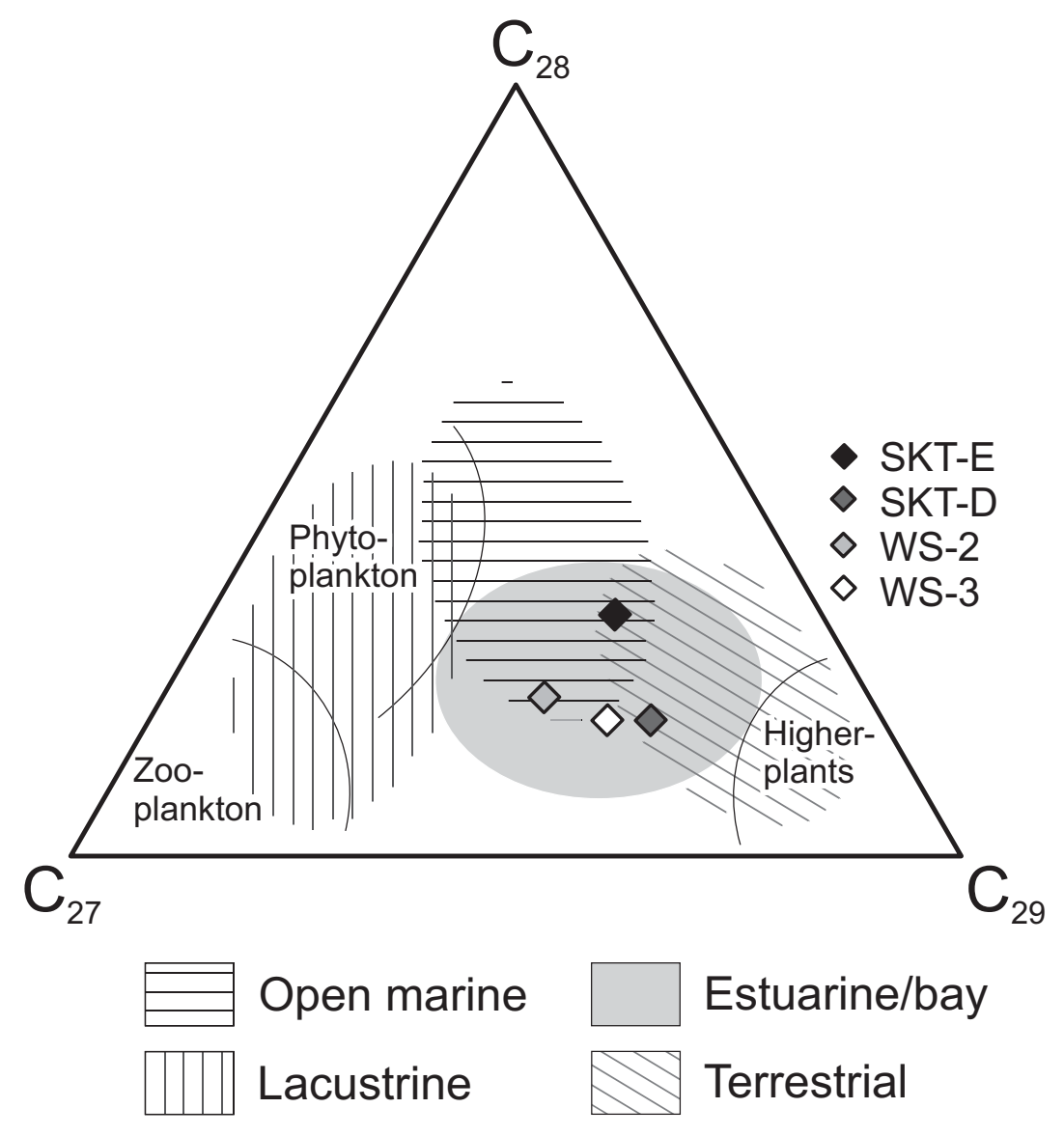



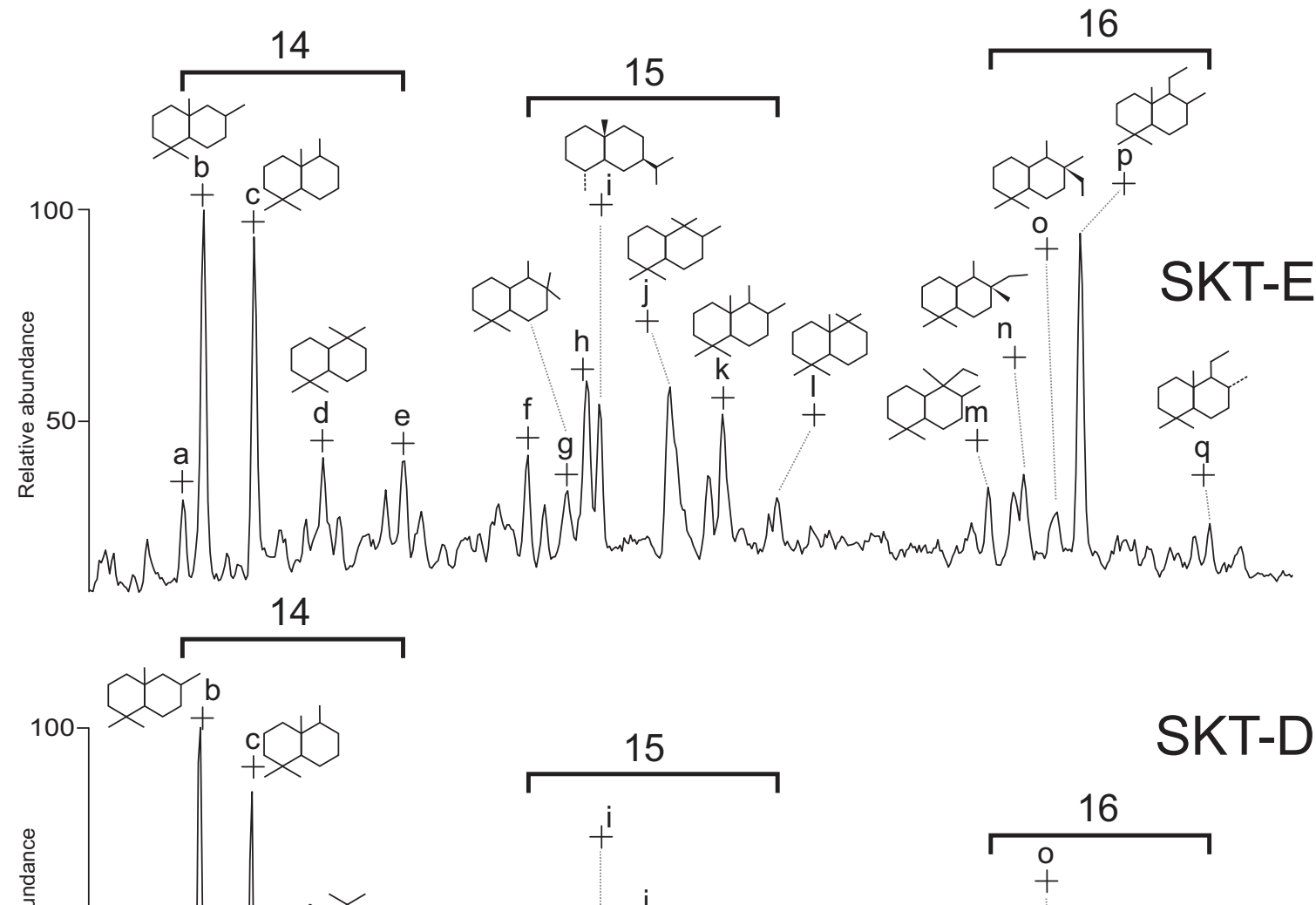

SKT-D
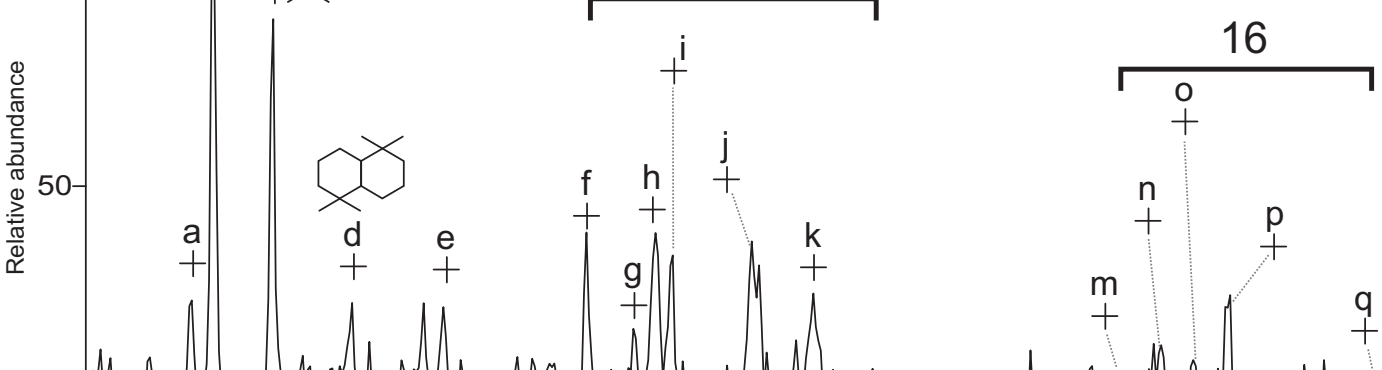

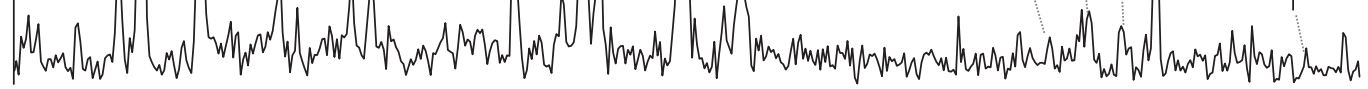
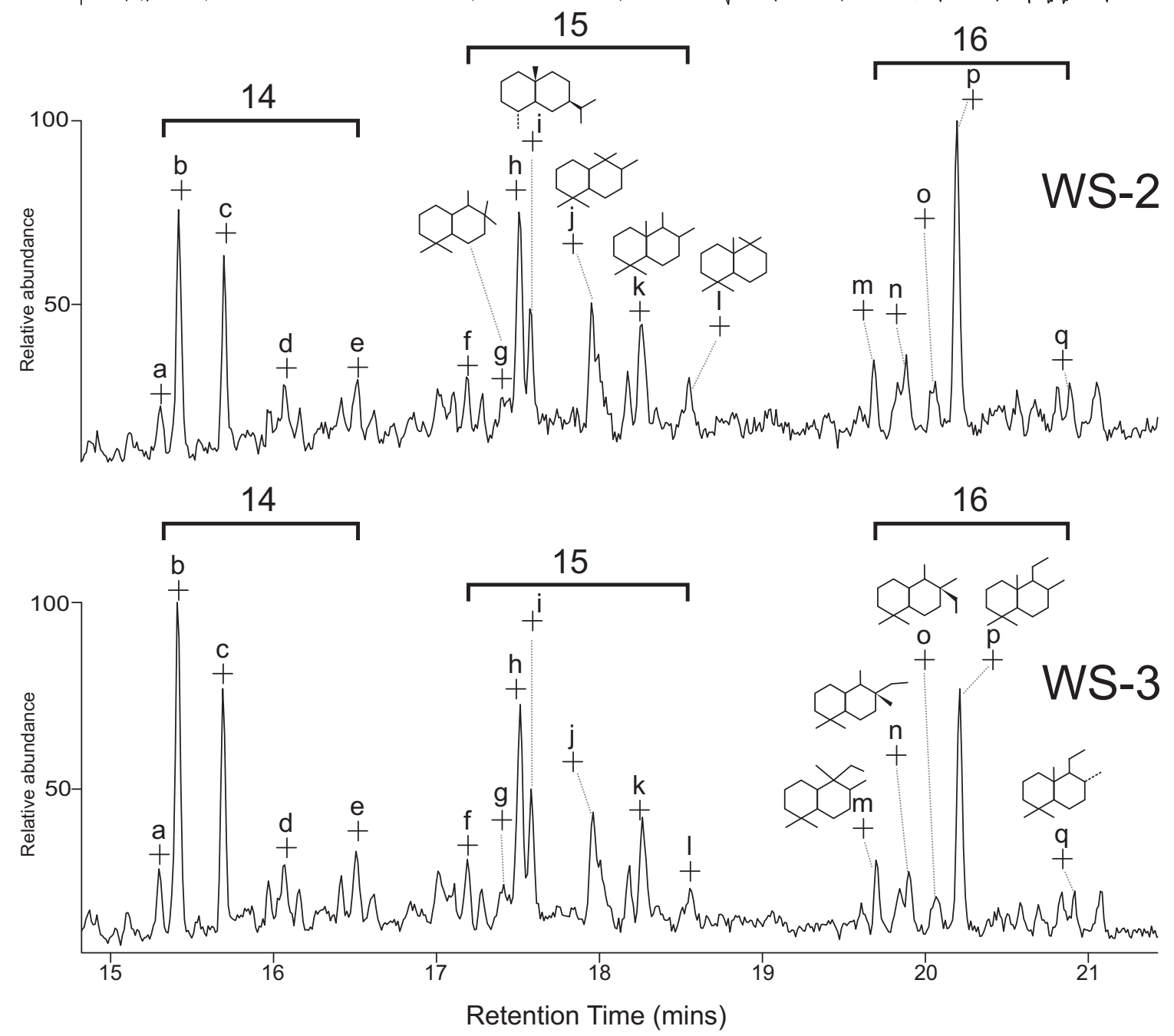

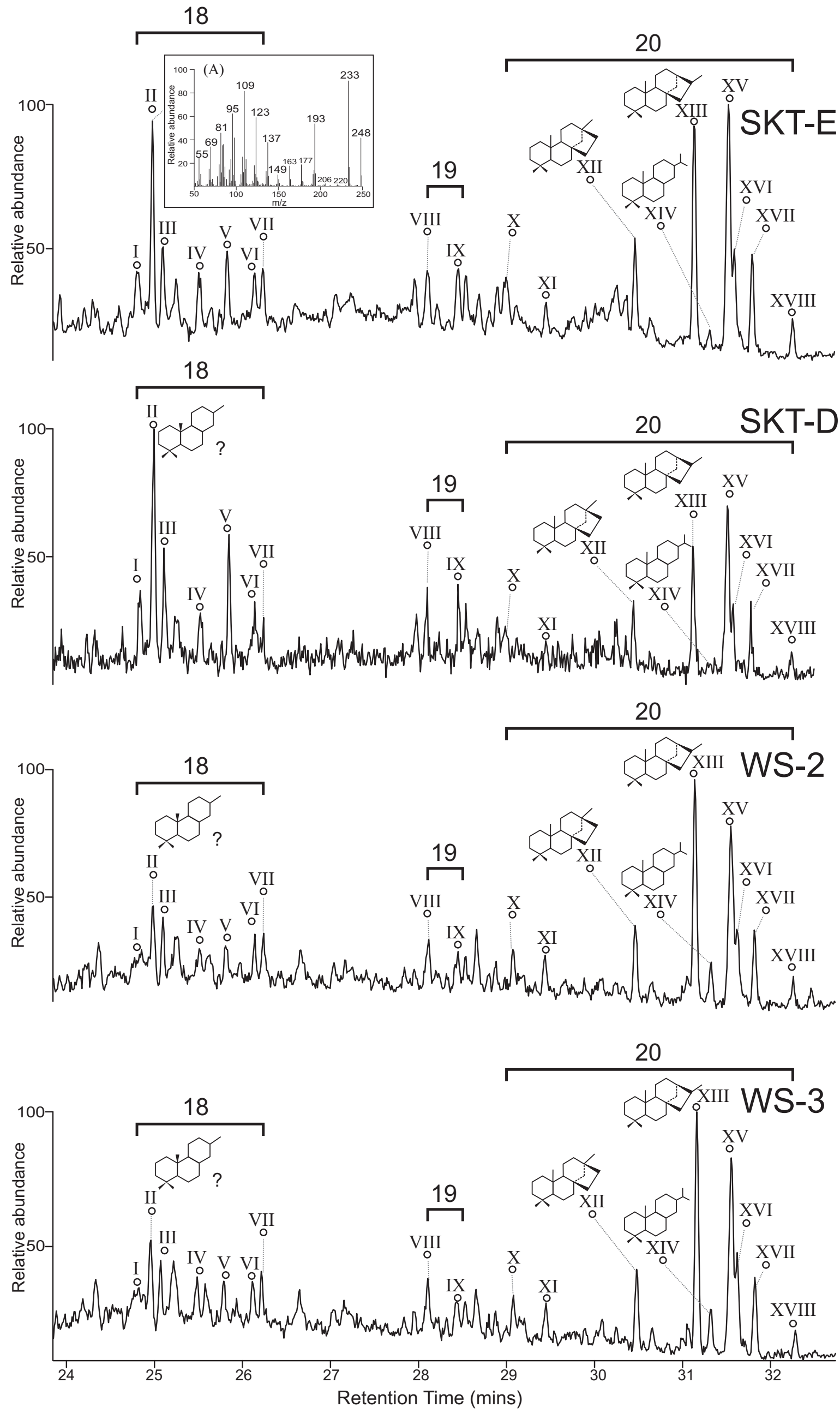


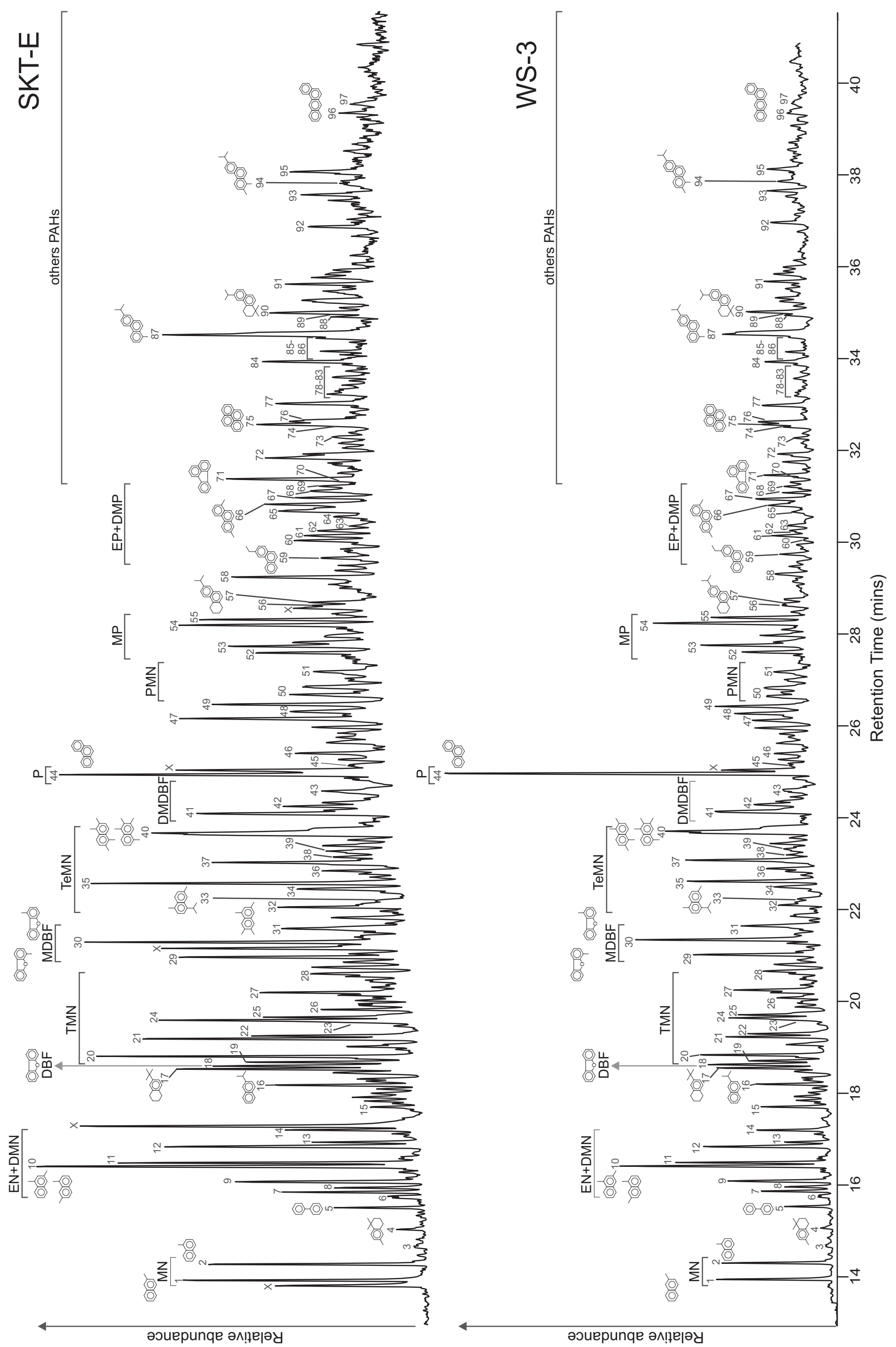



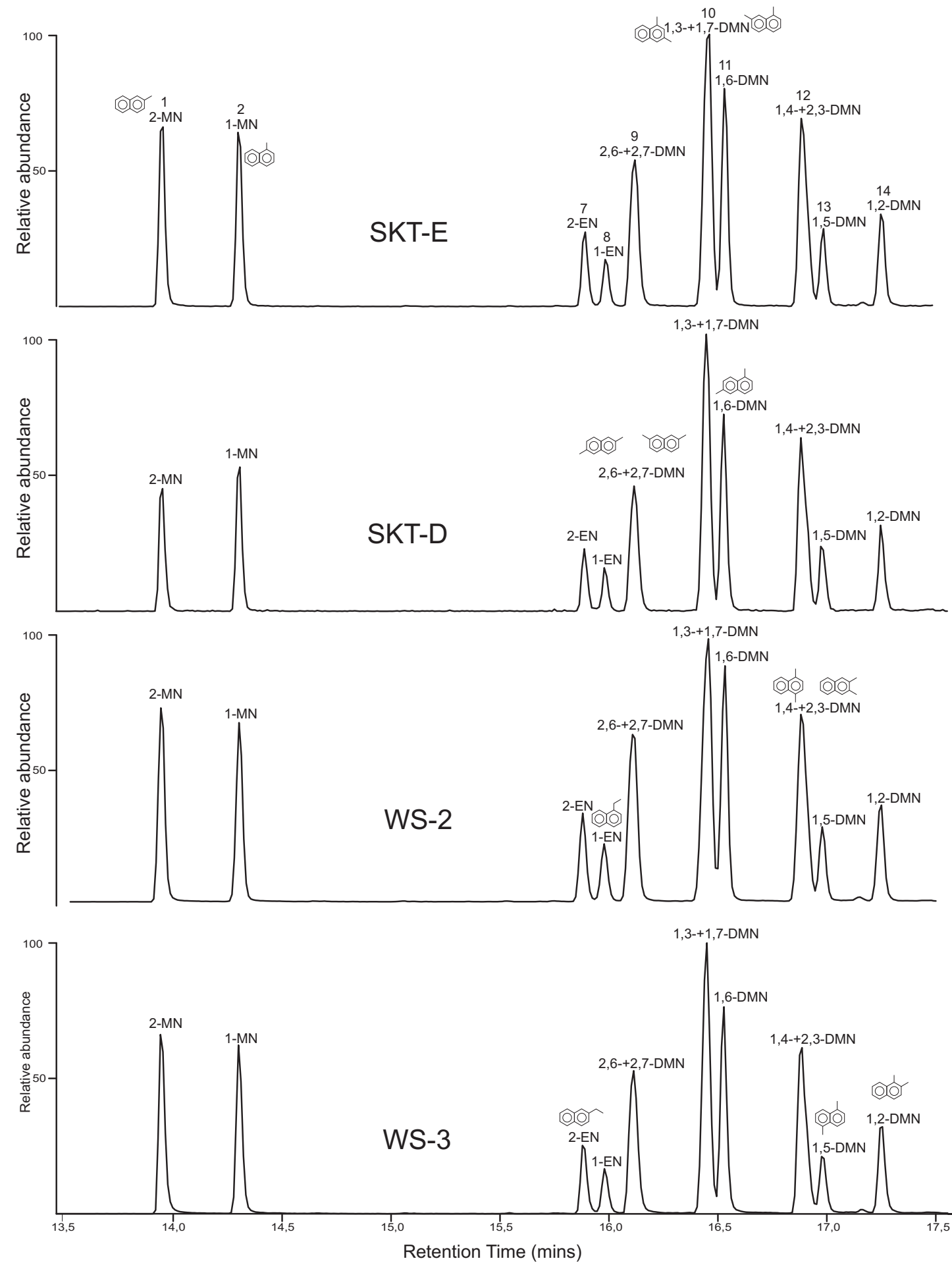


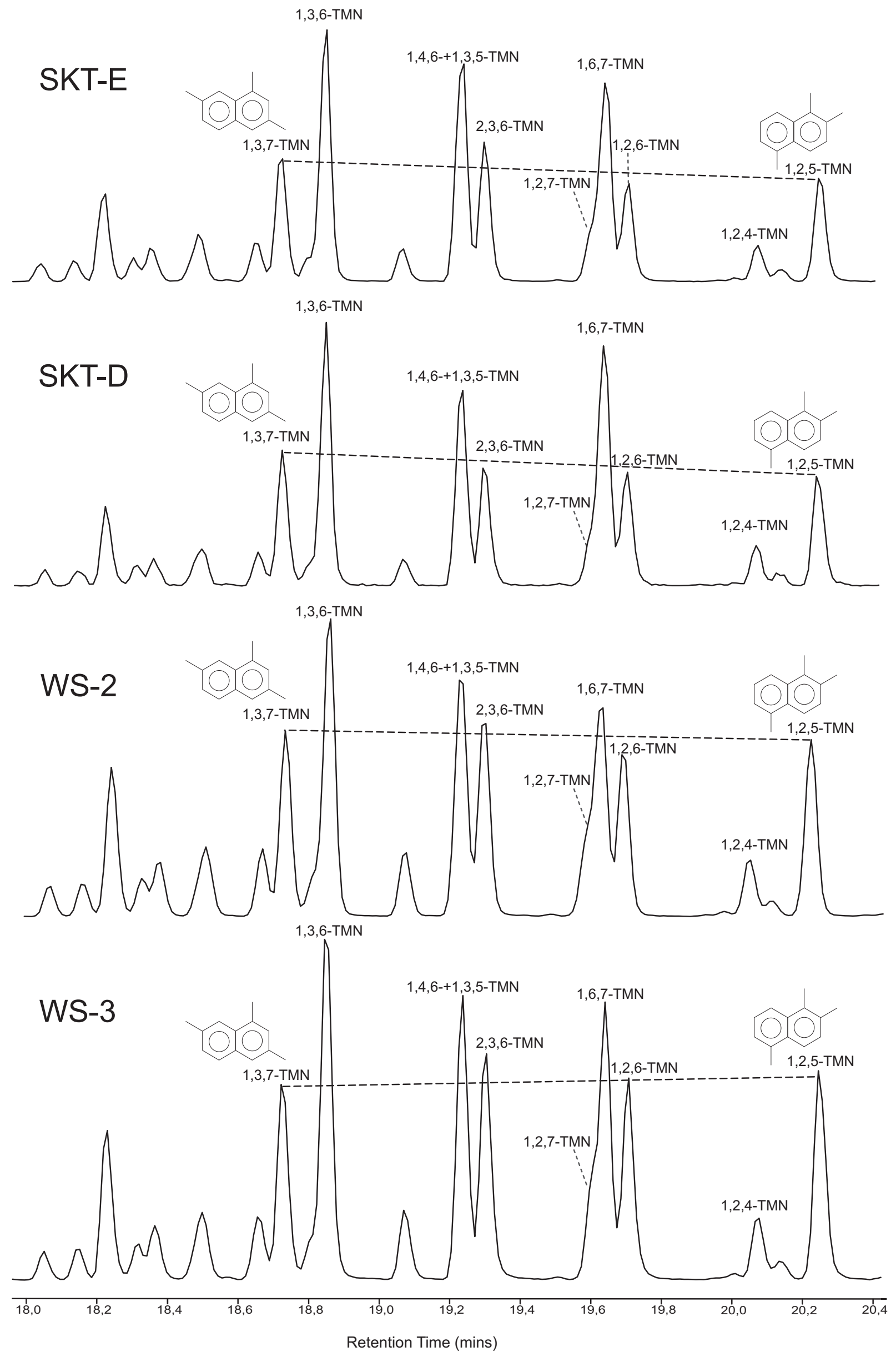



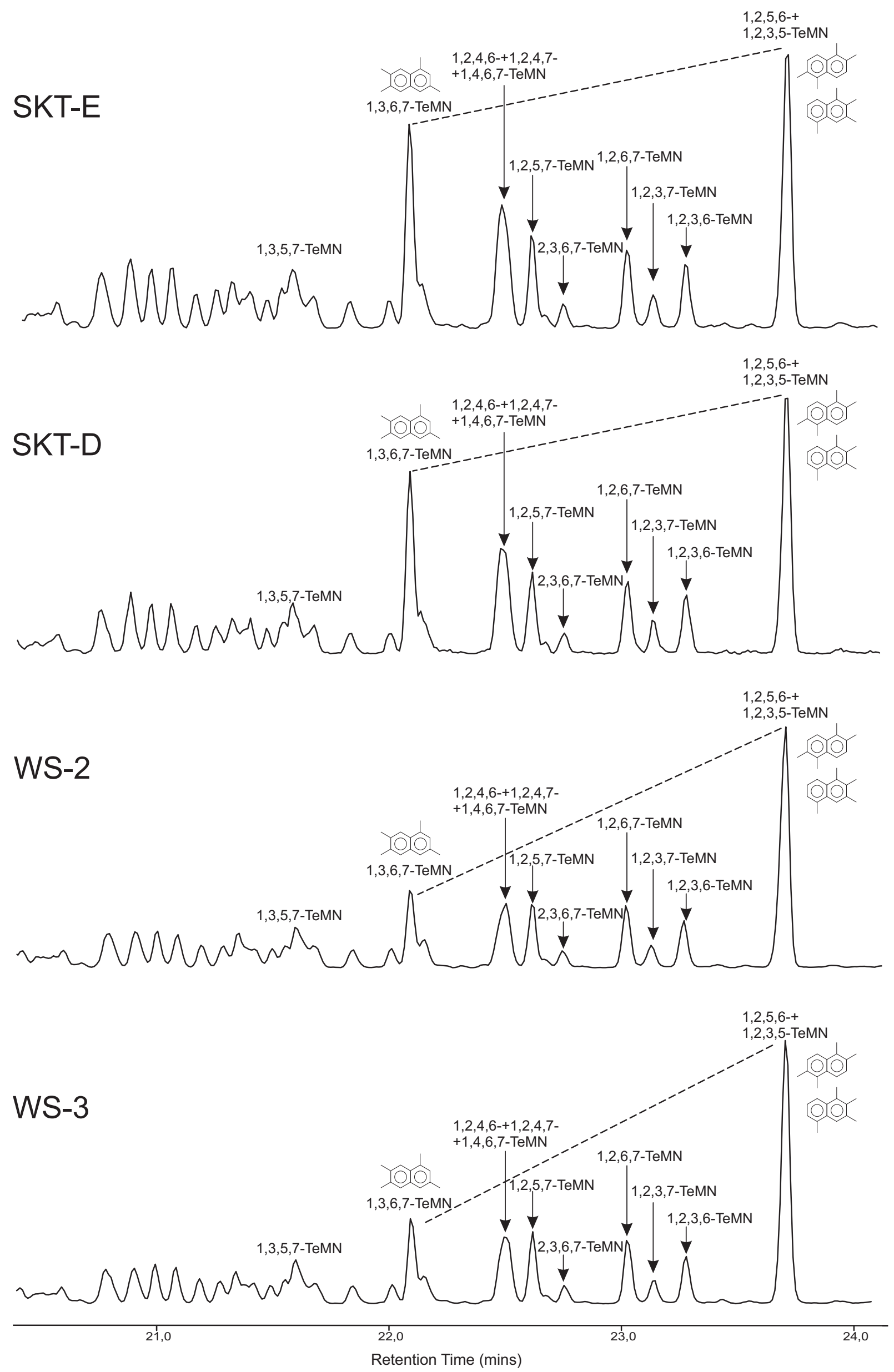


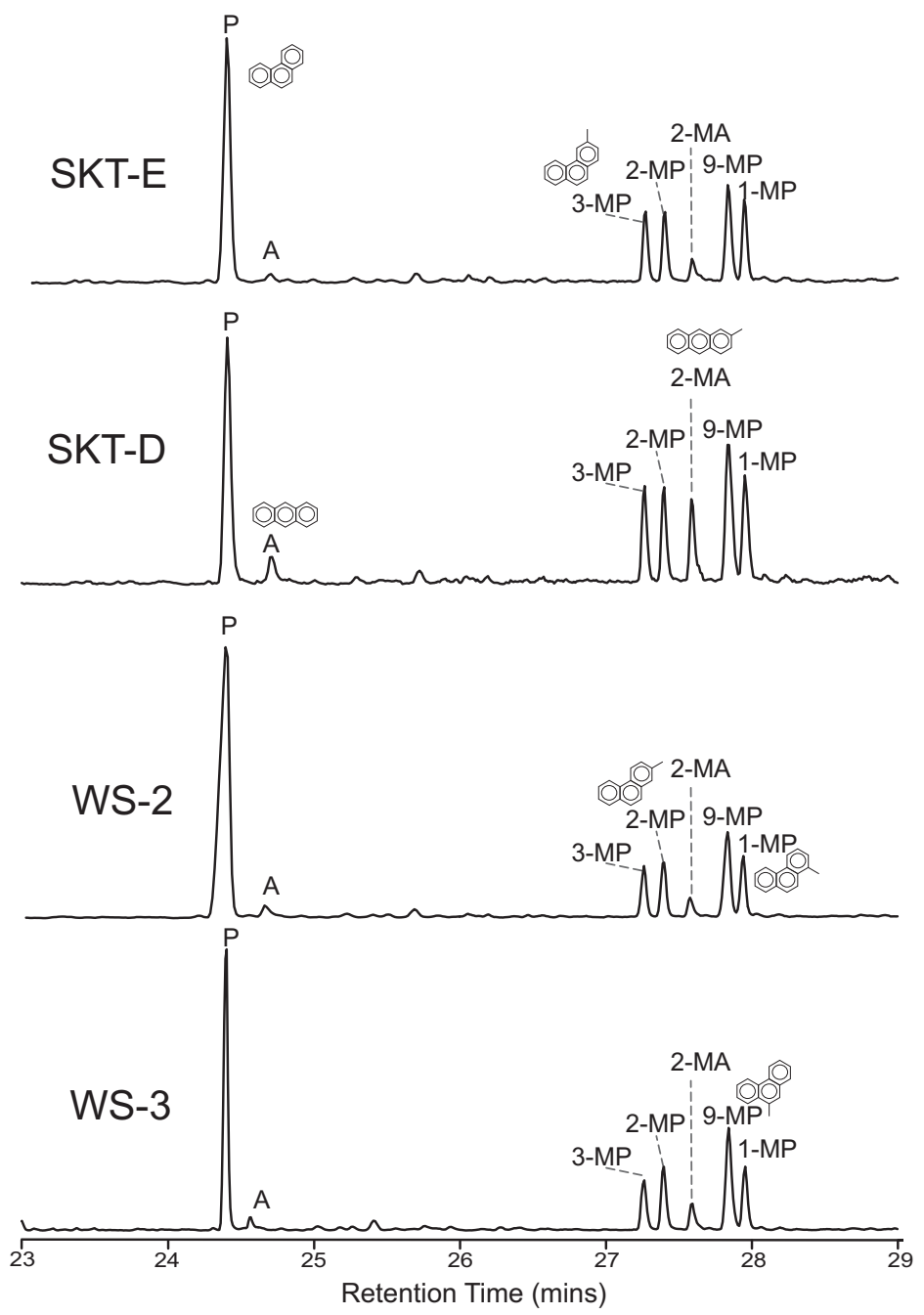




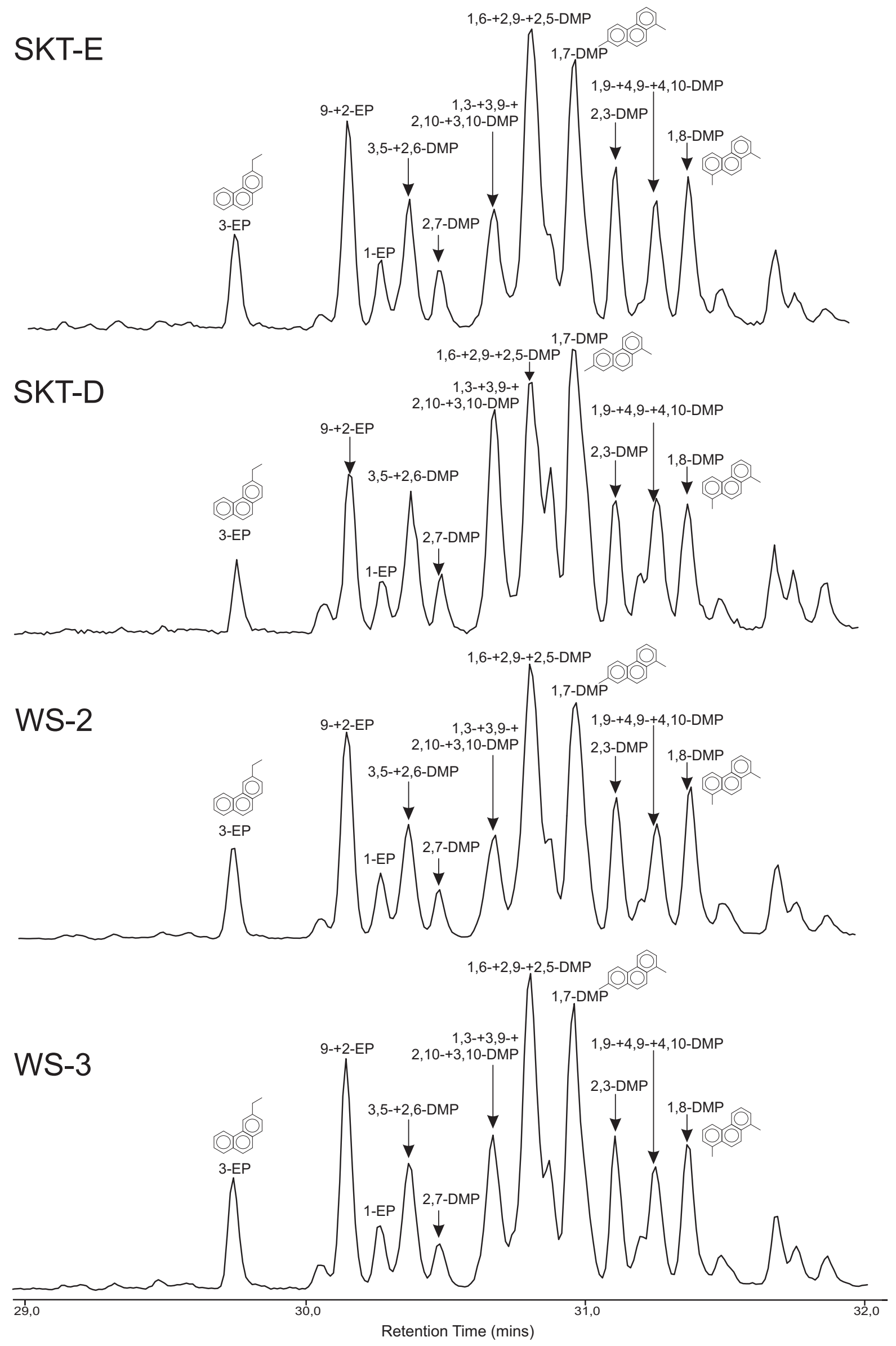




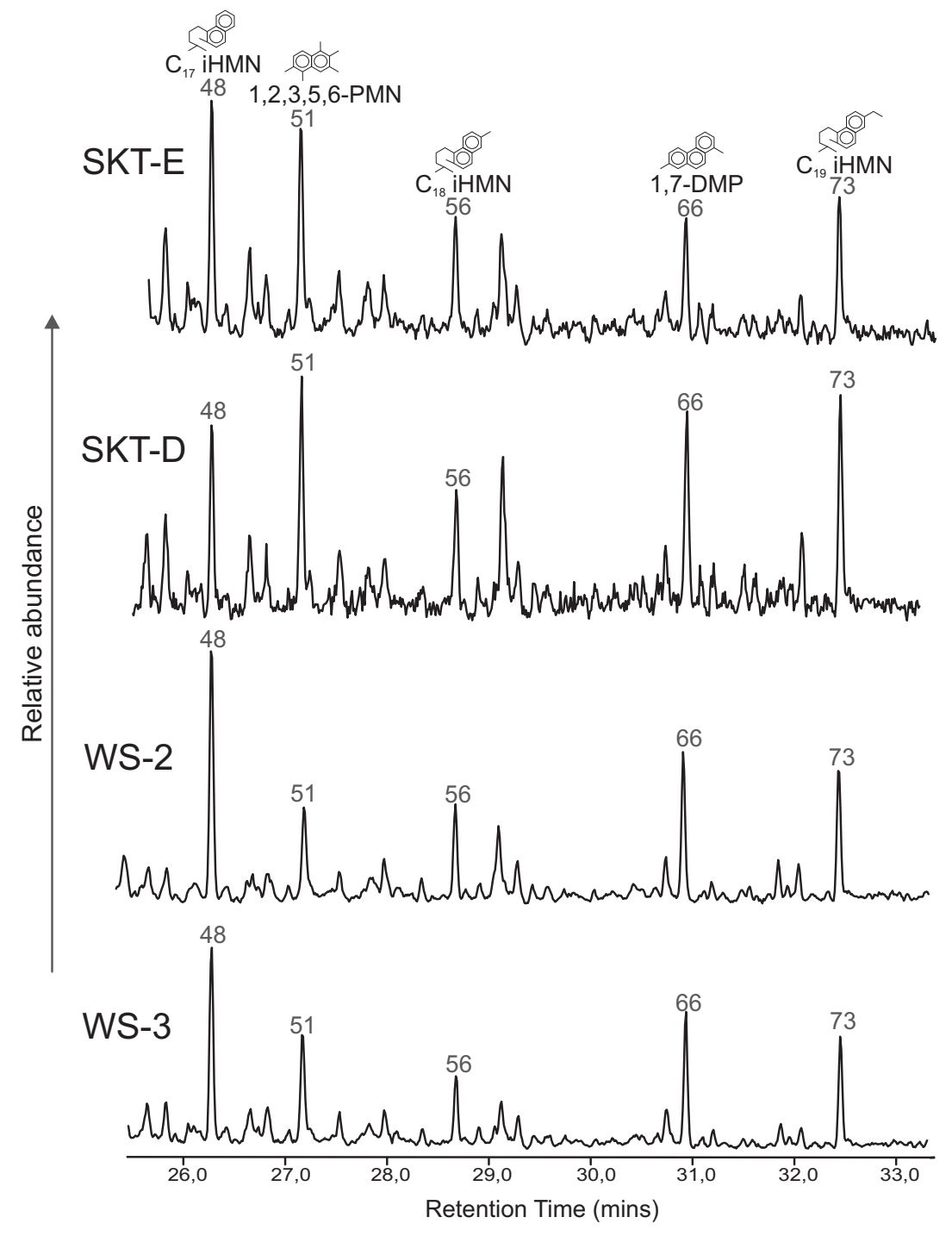



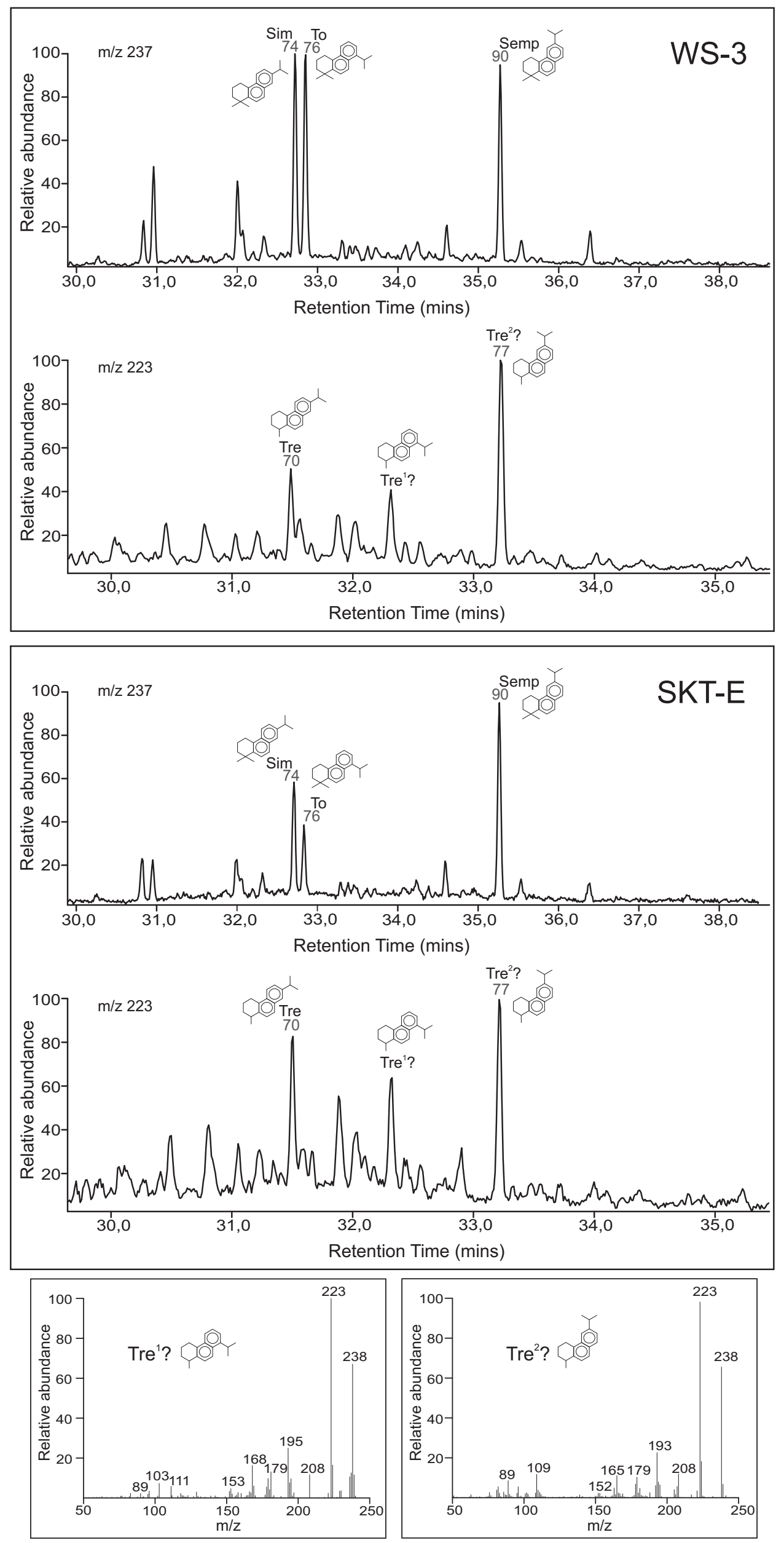


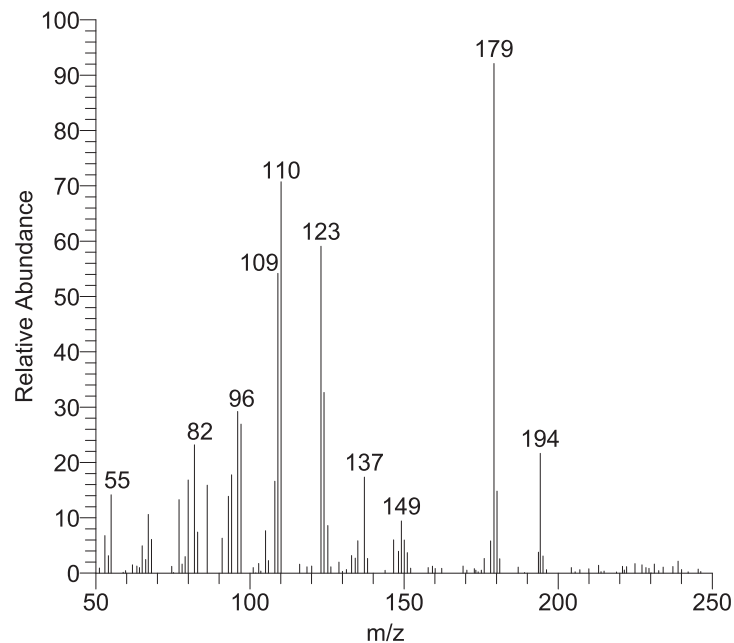

Peak a: $\mathrm{C}_{14}$ bicyclic alkane?

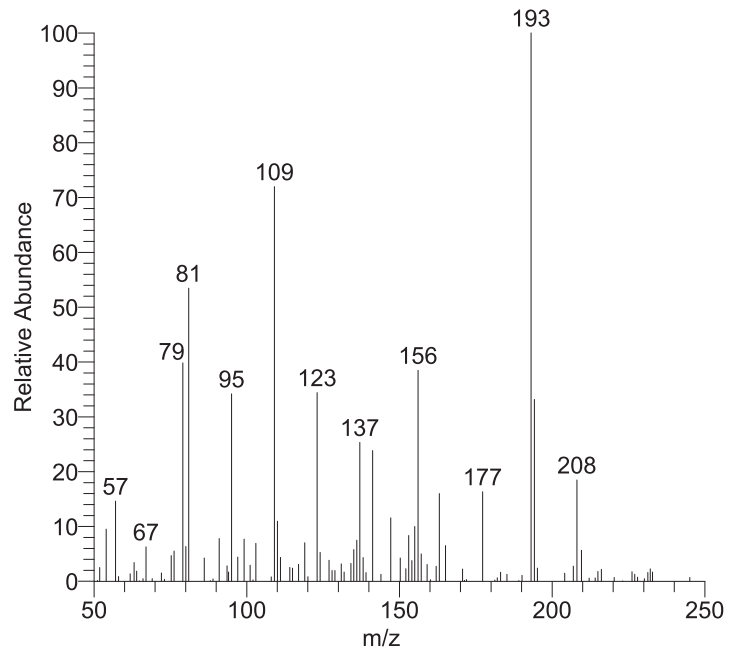

Peak f: $\mathrm{C}_{15}$ bicyclic alkane?

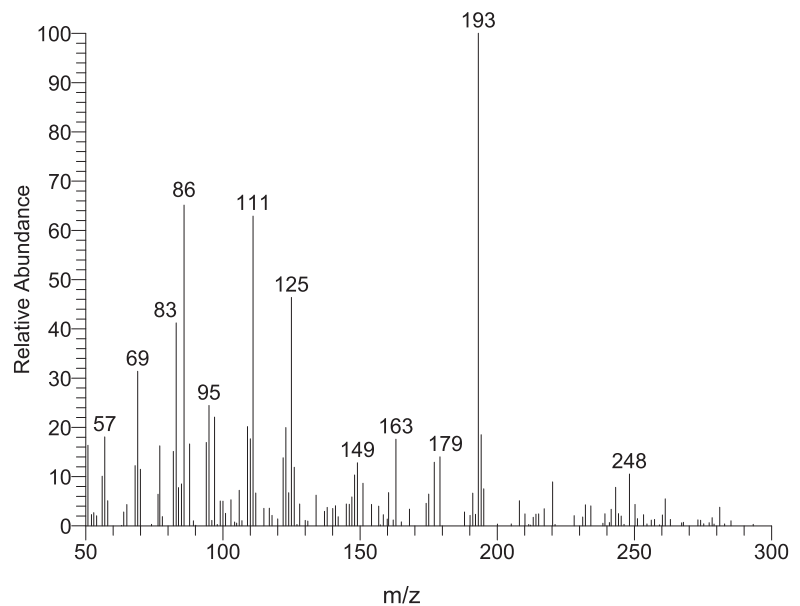

Peak I: $\mathrm{C}_{18}$ tricyclic hydrocarbon?

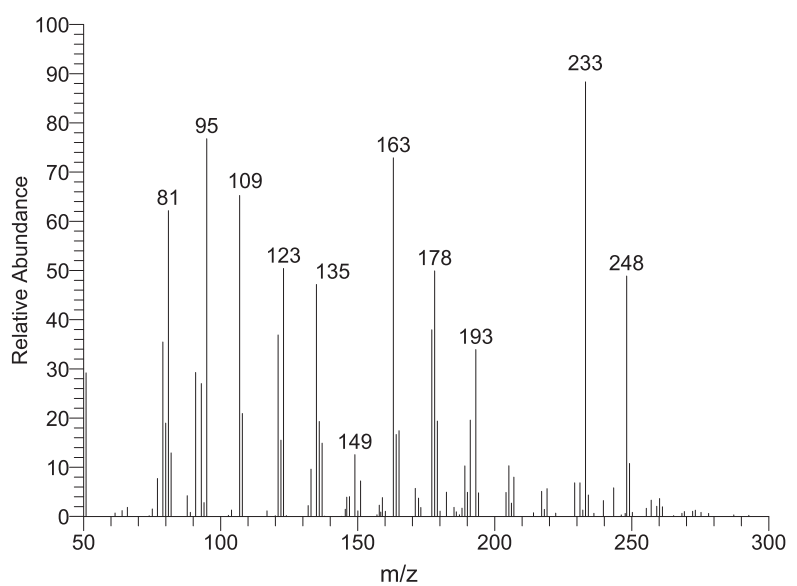

Peak IV: $\mathrm{C}_{18}$ tricyclic hydrocarbon?

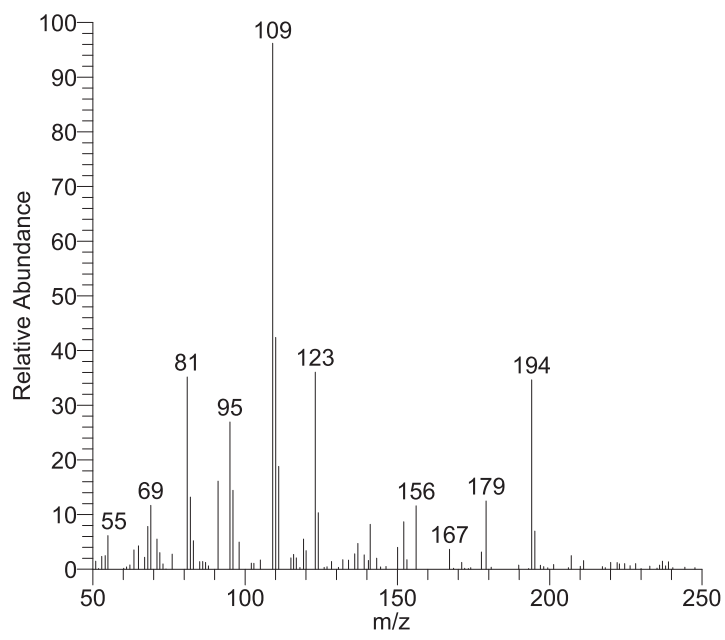

Peak e: $\mathrm{C}_{14}$ bicyclic alkane?

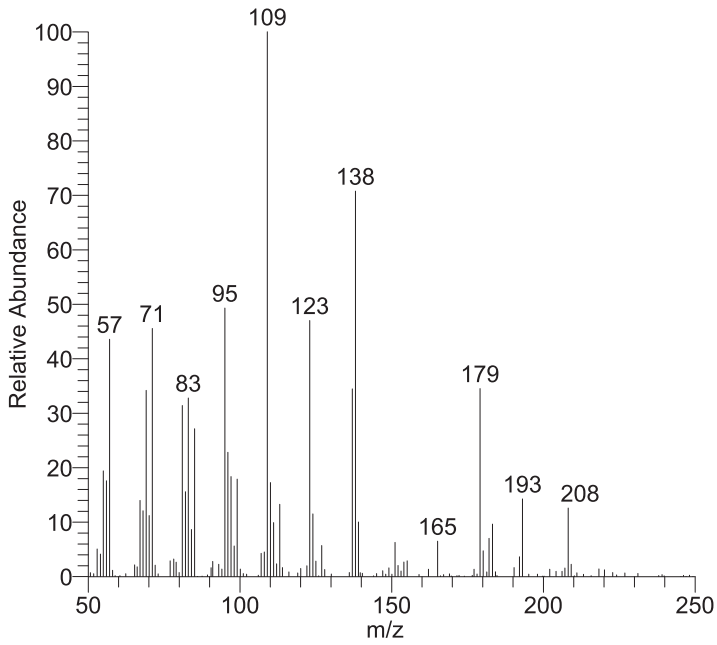

Peak h: $\mathrm{C}_{15}$ bicyclic alkane?

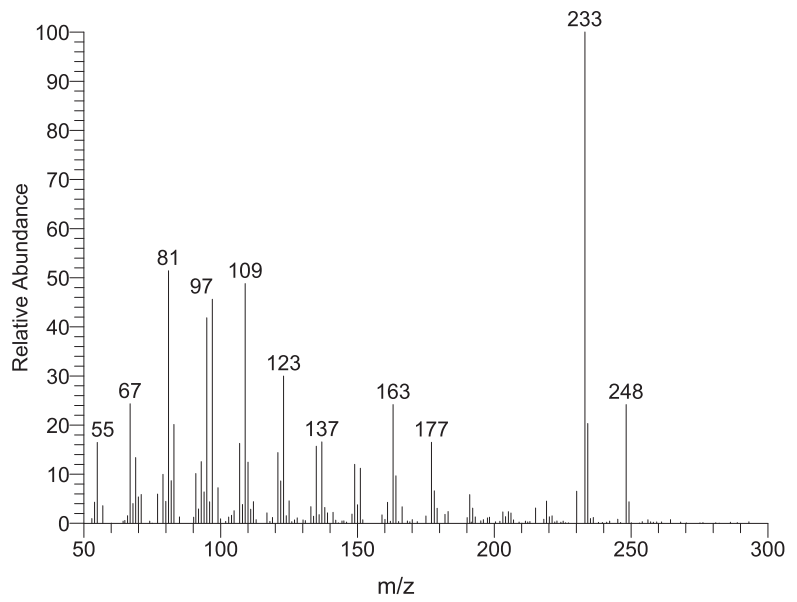

Peak III: $\mathrm{C}_{18}$ tricyclic hydrocarbon?

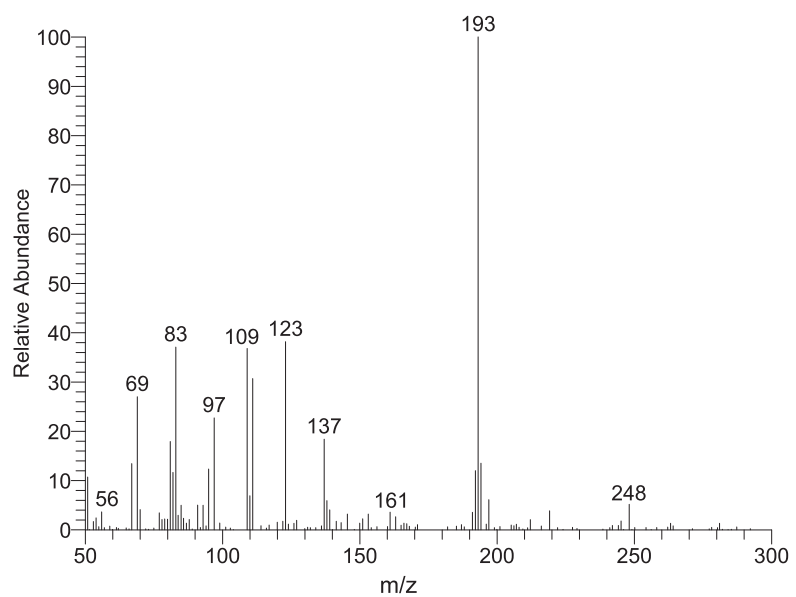

Peak V: $\mathrm{C}_{18}$ tricyclic hydrocarbon? 


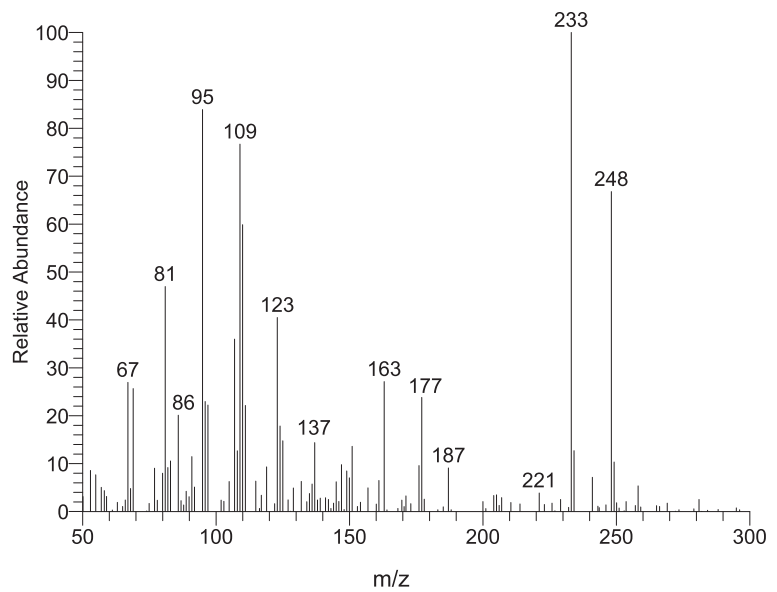

Peak VI: $\mathrm{C}_{18}$ tricyclic hydrocarbon?

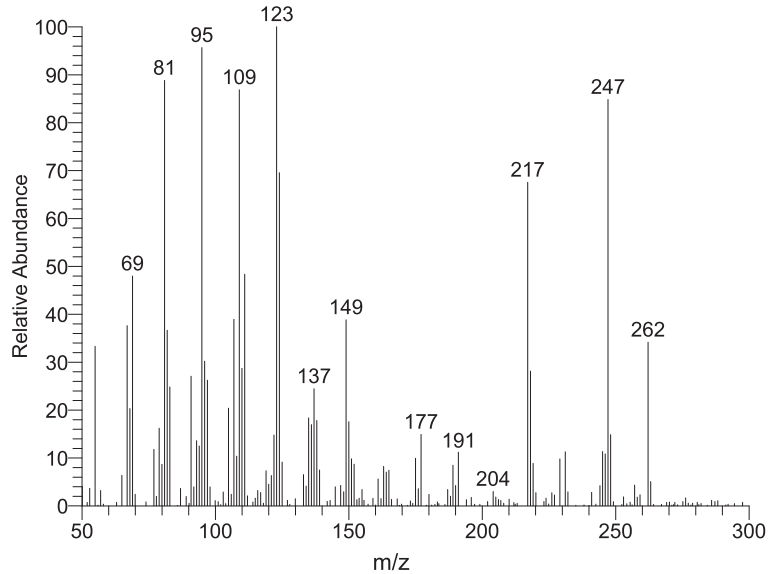

Peak VIII: $\mathrm{C}_{19}$ tricyclic hydrocarbon?

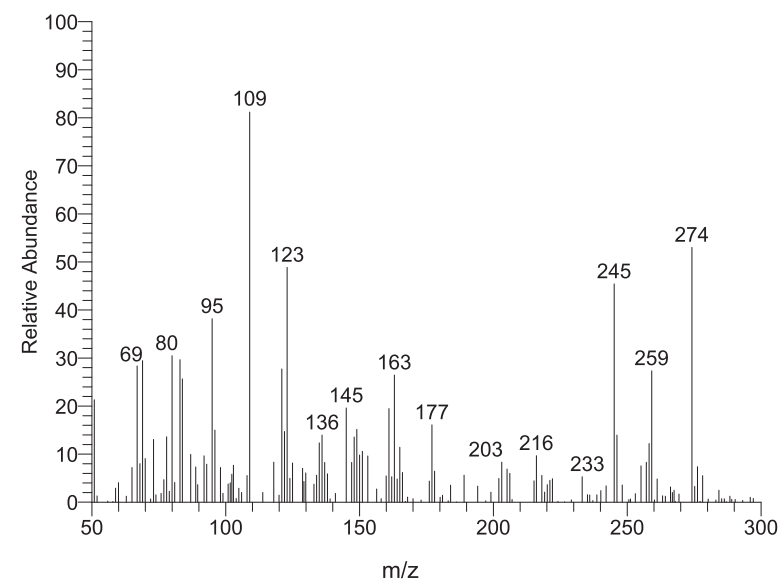

Peak X: $\mathrm{C}_{20}$ tretracyclic diterpenoid?

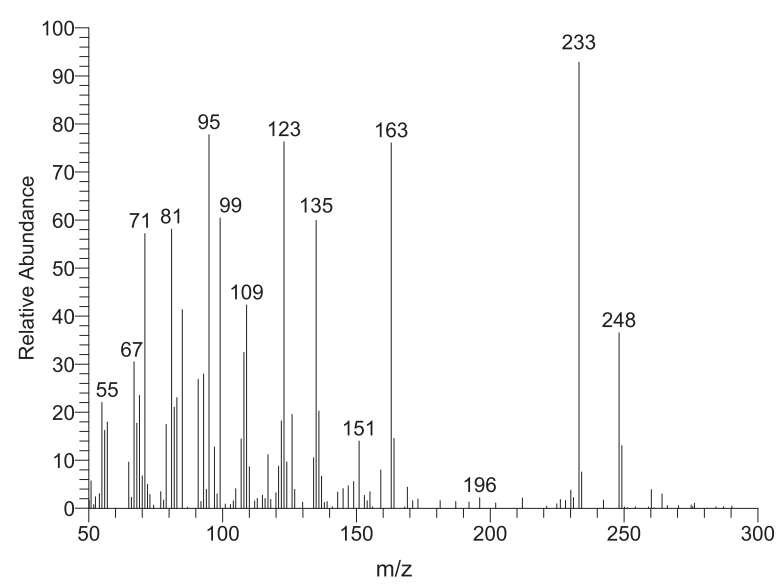

Peak VII: $\mathrm{C}_{18}$ tricyclic hydrocarbon?

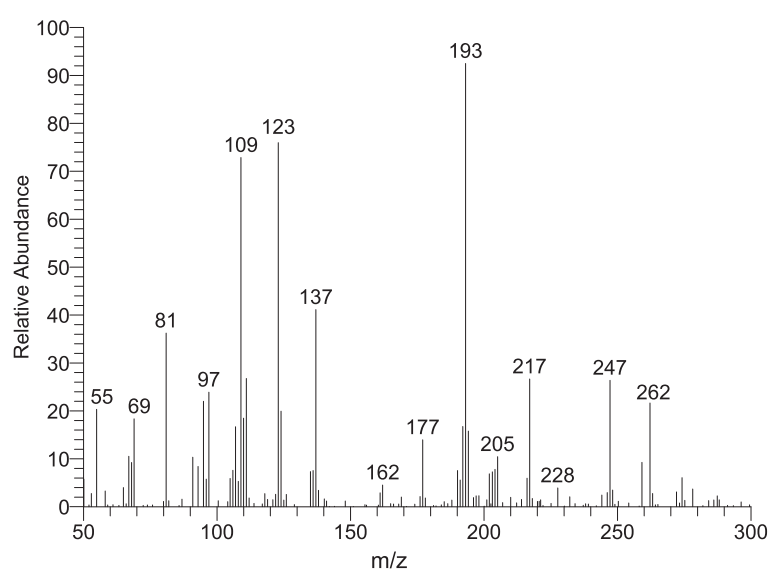

Peak IX: $\mathrm{C}_{19}$ tricyclic hydrocarbon?

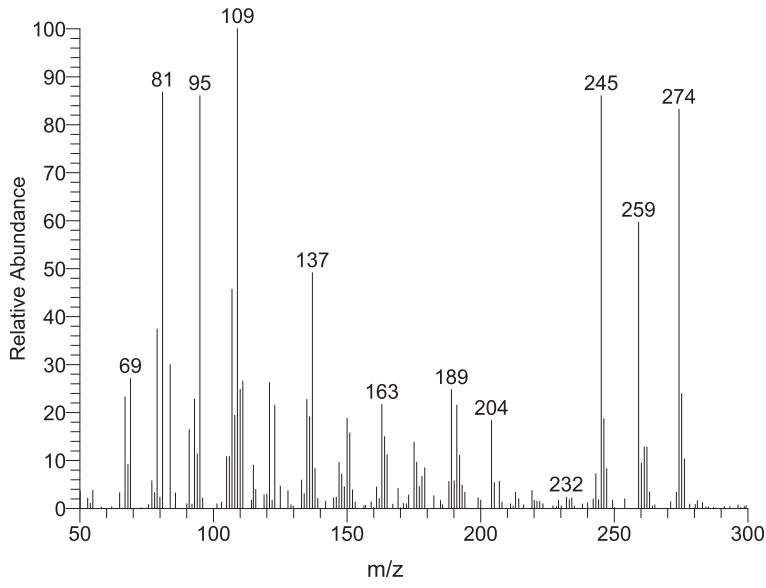

Peak XI: $\mathrm{C}_{20}$ tetracyclic diterpenoid?

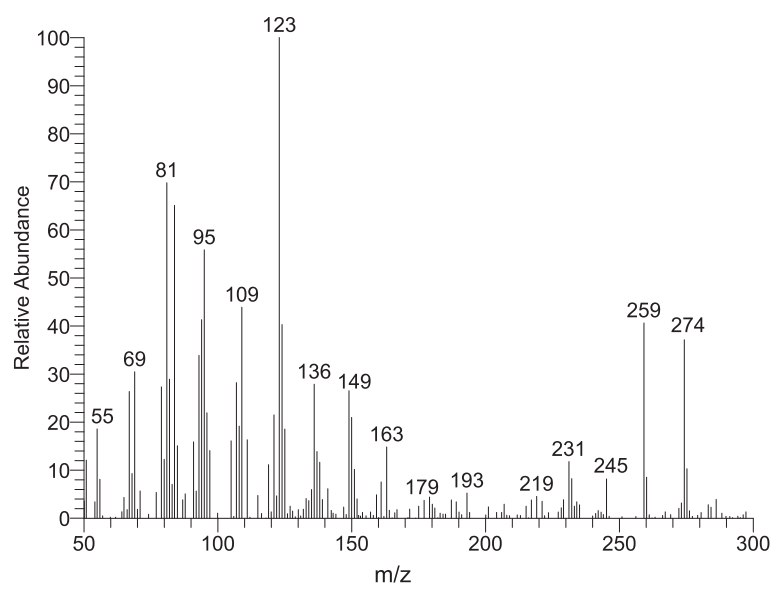

Peak XVIII: $\mathrm{C}_{20}$ tetracyclic diterpenoid? 